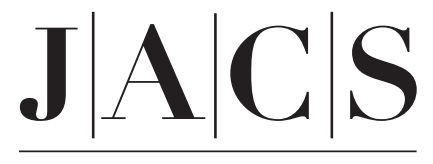

A R T I C L E S

Published on Web 11/10/2007

\title{
Intramolecular Cyclization of Ruthenium Vinylidene Complexes with a Tethering Vinyl Group: Facile Cleavage and Reconstruction of the $\mathrm{C}-\mathrm{C}$ Double Bond
}

\author{
Cheng-Wei Cheng, Yi-Chun Kuo, Shu-Hao Chang, Ying-Chih Lin,* \\ Yi-Hong Liu, and Yu Wang \\ Contribution from the Department of Chemistry, National Taiwan University, Taipei, \\ Taiwan 106, Republic of China
}

Received July 5, 2007; E-mail: yclin@ntu.edu.tw

\begin{abstract}
Protonation of ruthenium acetylide complexes $[\mathrm{M}]-{ }^{*} \mathrm{C} \equiv{ }^{*} \mathrm{CCPh}_{2} \mathrm{CH}_{2} \mathrm{CH}=\mathrm{CH}_{2}\left(\mathbf{2 a}\right.$, [M] $=\left(\eta^{5}\right.$ $\left.\mathrm{C}_{5} \mathrm{H}_{5}\right)\left(\mathrm{P}(\mathrm{OPh})_{3}\right)\left(\mathrm{PPh}_{3}\right) \mathrm{Ru} ; 2 \mathrm{a}^{\prime},[\mathrm{M}]=\left(\eta^{5}-\mathrm{C}_{5} \mathrm{H}_{5}\right)(\mathrm{dppp}) \mathrm{Ru} ;{ }^{*} \mathrm{C}={ }^{13} \mathrm{C}$-labeled carbon atom) with $\mathrm{HBF}_{4}$ in ether produces $\left[[\mathrm{M}]={ }^{*} \mathrm{C}=\mathrm{CHCH}_{2} \mathrm{CPh}_{2}{ }^{*} \mathrm{CH}=\mathrm{CH}_{2}\right]\left[\mathrm{BF}_{4}\right]\left(\mathbf{4}, \mathbf{4}^{\prime}\right)$ exclusively via a metathesis process of the terminal vinyl group with the ${ }^{*} \mathrm{C}={ }^{*} \mathrm{C}$ of the resulting vinylidene group. For $\mathbf{4}$ in methanol, bond reconstruction of the two labeled ${ }^{*} \mathrm{C}$ atoms readily takes place via a retro-metathesis process followed by a cyclization of the resulting vinylidene ligand giving the cyclic carbene complex $\mathbf{5}$, which is fully characterized by singlecrystal X-ray diffraction analysis. The protonation of $\mathbf{2 a}$ in $\mathrm{MeOH}$ is followed by a cyclization, also giving $\mathbf{5}$. Deuterium-labeling study indicates that the $\mathrm{C}-\mathrm{C}$ bond formation of this cyclization proceeds simultaneously with the formation of 4 consistent with facile cleavage and reconstruction of $\mathrm{C}=\mathrm{C}$ bonds. For comparison, complex $\mathbf{4}$ in alcohol yields, besides 5 , the corresponding alkoxycyclohexene $\mathbf{6}$. Formation of $\mathbf{6}$ from $\mathbf{4}$ also involves a skeletal rearrangement with reconstruction of the $\mathrm{C}=\mathrm{C}$ bond. Interestingly, $\left[\left[R u^{\prime}\right]={ }^{*} \mathrm{C}=\mathrm{C}(\mathrm{Me})\right.$ $\left.\mathrm{CH}_{2} \mathrm{CPh}_{2}{ }^{*} \mathrm{CH}=\mathrm{CH}_{2}\right]\left[\mathrm{BF}_{4}\right]\left(\mathbf{8}^{\prime}\right)$ originally from a complex with two connected labeled carbon atoms also undergoes reestablishment of the ${ }^{*} \mathrm{C}={ }^{*} \mathrm{C}$ bond yielding the cyclic allenyl complex $9^{\prime} .{ }^{13} \mathrm{C}$-labeling studies clearly reveal the reestablishment of two $\mathrm{C}=\mathrm{C}$ double bonds in the transformation of both $\mathbf{4}$ to $\mathbf{5}$ and $\mathbf{8}^{\prime}$ to 9'. The proposed mechanism implicates a cyclobutylidene intermediate formed either via a regiospecific [2+2] cycloaddition of two double bonds in the ruthenium vinylidene $\mathbf{4}$ or via a cyclization of $\mathbf{4}$ giving a nonclassical ion intermediate followed by a 1,2-alkyl shift.
\end{abstract}

\section{Introduction}

Reactions of enynes catalyzed by electrophilic late-transitionmetal complexes have attracted much attention because a variety of products can be obtained from fairly simple substrates under mild conditions. ${ }^{1}$ As a result of the compatibility and the utilization of very diverse precursors, the metal-catalyzed cycloisomerization of enyne systems has recently expanded on synthetically versatile developments, including notably applications in the total synthesis of natural products. ${ }^{2}$ Metal-catalyzed cycloisomerization of enynes often leads to various skeletal rearrangements because "nonclassical" cations may participate as reaction intermediates. ${ }^{3}$ For example, transition-metalcatalyzed cycloisomerization of 1,6-enynes represents an efficient strategy for a variety of five-membered and sixmembered alkenes and dienes. ${ }^{4}$ The corresponding metal-

(1) (a) Chatani, N.; Kataoka, K.; Murai, S.; Furukawa, N.; Seki, Y. J. Am Chem. Soc. 1998, 120, 9104. (b) Trost, B. M.; Doherty, G. A. J. Am. Chem. Soc. 2000, 122, 3801. (c) Méndez, M.; Muñoz, M. P.; Nevado, C.; Cárdenas, D. J.; Echavarren, A. M. J. Am. Chem. Soc. 2001, 123, 10511. (d) MartínMatute, B.; Nevado, C.; Cárdenas, D. J.; Echavarren, A. M. J. Am. Chem. Soc. 2003, 125, 5757. (e) Ma, S.; Yu, S.; Gu, Z. Angew. Chem., Int. Ed. 2006, 45, 200. (f) Zhang, L.; Sun, J.; Kozmin, S. A. Adv. Synth. Catal. 2006, 348, 2271.

(2) (a) Fürstner, A.; Stelzer, F.; Szillat, H. J. Am. Chem. Soc. 2001, 123, 11863. (b) Fürstner, A.; Szillat, H.; Gabor, B.; Mynott, R. J. Am. Chem. Soc. 1998 120, 8305. (c) Charruault, L.; Michelet, V.; Taras, R.; Gladiali, S.; Genêt, J. P. Chem. Commun. 2004, 850.

14974 a J. AM. CHEM. SOC. 2007, 129, 14974-14980 catalyzed cycloisomerizations of 1,5-enynes have been much less investigated; however, the known reactivities of 1,5-enynes also involve the same type of cycloisomerization. ${ }^{5}$ On the other hand, this very same diversity can be viewed as a disadvantage from the synthetic viewpoint that the outcome of a specific transformation may be difficult to predict. Therefore, further insight into the mechanism of these transformations is desirable. ${ }^{6}$

Herein, we describe the development of ruthenium-mediated isomerizations of 1,5-enynes to furnish the other type of 1,5enynes and cycloisomerizations to produce alkoxycyclohexenes. This process was supported by our recent discovery of the ruthenium-mediated skeletal rearrangement of 3,3-diphenyl-5-

(3) (a) Aubert, C.; Buisine, O.; Malacria, M. Chem. Rev. 2002, 102, 813. (b) Trost, B. M.; Krische, M. J. Synlett 1998, 1. (c) Ojima, I.; Tzamarioudaki, M.; Li, Z.; Donovan, R. J. Chem. Rev. 1996, 96, 635. (d) Oi, S.; Tsukamoto, I.; Miyano, S.; Inoue, Y. Organometallics 2001, 20, 3704.

(4) (a) Driver, S. T.; Geissert, A. J. Chem. Rev. 2004, 104, 1317. (b) Nevado, C.; Cárdenas, D. J.; Echavarren, A. M. Chem.-Eur. J. 2003, 9, 2627.

(5) (a) Mamane, V.; Gress, T.; Krause, H.; Fürstner, A. J. Am. Chem. Soc 2004, 126, 8654. (b) Harrak, Y.; Blaszykowski, C.; Bernard, M.; Cariou, K.; Mainetti, E.; Mouries, V.; Dhimane, A. L.; Fensterbank, L.; Malacria, M. J. Am. Chem. Soc. 2004, 126, 8656. (c) Nieto-Oberhuber, C.; Muñoz, M. P.; Buñuel, E.; Nevado, C.; Cárdenas, D. J.; Echavarren, A. M. Angew. Chem., Int. Ed. 2004, 43, 2402.

(6) (a) Méndez, M.; Mamane, V.; Fürstner, A. Chemtracts: Org. Chem. 2003 16, 397. (b) Lloyd-Jones, G. C. Org. Biomol. Chem. 2003, 1, 215. (c) NietoOberhuber, C.; López, S.; Jiménez-Núñez, E.; Echavarren, A. M. Chem. Eur. J. 2006, 12, 5916. (d) Echavarren, A. M.; Nevadoa, C. Chem. Soc. Rev. 2004, 33, 431

10.1021/ja074951p CCC: $\$ 37.00$ @ 2007 American Chemical Society 
Scheme 1

$[\mathrm{M}]=[\mathrm{Ru}]=\mathrm{Cp}\left(\mathrm{P}(\mathrm{OPh})_{3}\right)\left(\mathrm{PPh}_{3}\right) \mathrm{Ru}$

$\mathbf{n}^{\prime},[\mathrm{M}]=\left[\mathrm{Ru} \mathbf{u}^{\prime}\right]=\mathrm{Cp}(\mathrm{dppp}) \mathrm{Ru}$

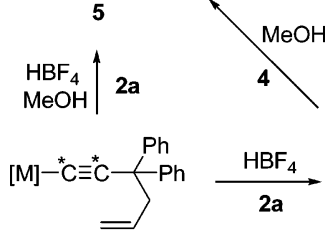

2a, 2a'

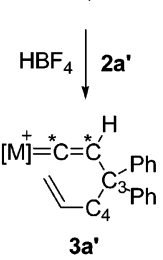<smiles>[W]=C1C=CCC(c2ccccc2)C1c1ccccc1</smiles>
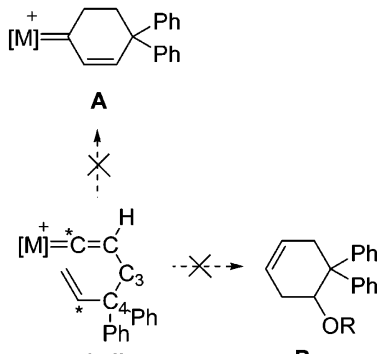

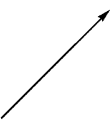

$4,4^{\prime}$

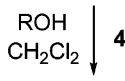

$5+* \underbrace{\sum_{O R}^{P h} P h}_{O R}$

6a, $\mathrm{R}=\mathrm{H} ; \mathbf{6 b}, \mathrm{R}=\mathrm{Me}$

6c, $R=E t ; 6 d, R={ }^{i} P r$ en-1-yne, which was proposed to proceed via an unusual mechanism involving a new metathesis process of the terminal vinyl group with the $\mathrm{C}=\mathrm{C}$ of the vinylidene group. ${ }^{7}$ Elucidation of this novel reaction mechanism enabled us to extend the scope of the ruthenium fragment.

\section{Results and Discussion}

Cleavage of Two $\mathbf{C}=\mathbf{C}$ Bonds. Metathesis of two $\mathrm{C}=\mathrm{C}$ double bonds in a vinylidene complex of $\mathrm{Cp}\left(\mathrm{PPh}_{3}\right)_{2} \mathrm{Ru}(\mathrm{Cp}=$ $\left.\eta^{5}-\mathrm{C}_{5} \mathrm{H}_{5}\right)$ system containing a tethering vinyl group was recently reported by us. ${ }^{7}$ The same metathesis is also observed in similar vinylidene complexes of $\mathrm{Cp}\left(\mathrm{P}(\mathrm{OPh})_{3}\right)\left(\mathrm{PPh}_{3}\right) \mathrm{Ru}$ and $\mathrm{Cp}(\mathrm{dppp})$ $\mathrm{Ru}$ described below. The reaction of $[\mathrm{Ru}] \mathrm{Cl}([\mathrm{Ru}]=\mathrm{Cp}$ $\left.\left(\mathrm{P}(\mathrm{OPh})_{3}\right)\left(\mathrm{PPh}_{3}\right) \mathrm{Ru}\right)$ with $\mathrm{HC} \equiv \mathrm{CC}(\mathrm{Ph})_{2} \mathrm{OH}$ in dichloromethane at room temperature gives the ruby red allenylidene complex $\left[[\mathrm{Ru}]=\mathrm{C}=\mathrm{C}=\mathrm{C}(\mathrm{Ph})_{2}\right]\left[\mathrm{PF}_{6}\right]^{8}(\mathbf{1})$ in high yield. Similarly, the allenylidene complex $\left[\left[\mathrm{Ru}^{\prime}\right]=\mathrm{C}=\mathrm{C}=\mathrm{C}(\mathrm{Ph})_{2}\right]\left[\mathrm{PF}_{6}\right]\left(\mathbf{1}^{\prime},\left[\mathrm{Ru}^{\prime}\right]=\right.$ $\mathrm{Cp}(\mathrm{dppp}) \mathrm{Ru})$ is also obtained in high yield. Regioselective nucleophilic addition is commonly observed at $\mathrm{C}_{\gamma}$ of the allenylidene ligand, ${ }^{9}$ and by means of this reaction we synthesize neutral $\sigma$-alkynyl complexes $[\mathrm{M}]-\mathrm{C} \equiv \mathrm{CC}(\mathrm{Ph})_{2} \mathrm{CH}_{2} \mathrm{CH}=\mathrm{CH}_{2}$

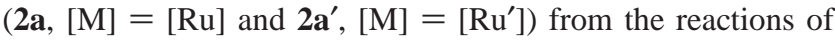
Grignard reagent $\mathrm{CH}_{2}=\mathrm{CHCH}_{2} \mathrm{MgCl}$ with $\mathbf{1}$ and $\mathbf{1}^{\prime}$, respectively. Treatment of the $\sigma$-alkynyl complex $\mathbf{2} \mathbf{a}^{\prime}$ with $\mathrm{HBF}_{4}$ in diethyl ether at $-20{ }^{\circ} \mathrm{C}$ generates in high yield the vinylidene complex $\left[\left[\mathrm{Ru}^{\prime}\right]=\mathrm{C}=\mathrm{CHC}(\mathrm{Ph})_{2} \mathrm{CH}_{2} \mathrm{CH}=\mathrm{CH}_{2}\right]\left[\mathrm{BF}_{4}\right]\left(\mathbf{3 a}^{\prime}\right)$, which in dichloromethane transforms to the other vinylidene complex $\left[\left[\mathrm{Ru}^{\prime}\right]=\right.$ $\left.\mathrm{C}=\mathrm{CHCH}_{2} \mathrm{C}(\mathrm{Ph})_{2} \mathrm{CH}=\mathrm{CH}_{2}\right]\left[\mathrm{BF}_{4}\right]\left(4^{\prime}\right)$ at room temperature. However, protonation of 2a yields the vinylidene complex $\mathbf{4}$ directly, and the anticipated vinylidene complex $[[\mathrm{Ru}]=\mathrm{C}=$ $\left.\mathrm{CHC}(\mathrm{Ph})_{2} \mathrm{CH}_{2} \mathrm{CH}=\mathrm{CH}_{2}\right]\left[\mathrm{BF}_{4}\right]$ (3a) is too reactive to be isolated (Scheme 1). The much faster rate of the formation of $\mathbf{4}$ as compared to that of the dppp analogue $4^{\prime}$ is ascribed to the

(7) Yen, Y. S.; Huang, S. L.; Liu, Y. H.; Sung, H. L.; Wang, Y.; Lin, Y. C. J. Am. Chem. Soc. 2005, 127, 18037.

(8) Selegue, J. P. Organometallics 1982, 1, 217

(9) (a) Esteruelas, M. A.; Gómez, A.; López, A. M.; Modrego, J.; Oñate, E. Organometallics 1997, 16, 5826. (b) Cadierno, V.; Gamasa, M. P.; Gimeno, J.; González-Cueva, M.; Lastra, E.; Borge, J.; García-Granda, S.; PérezCarrenõ, E. Organometallics 1996, 15, 2137.

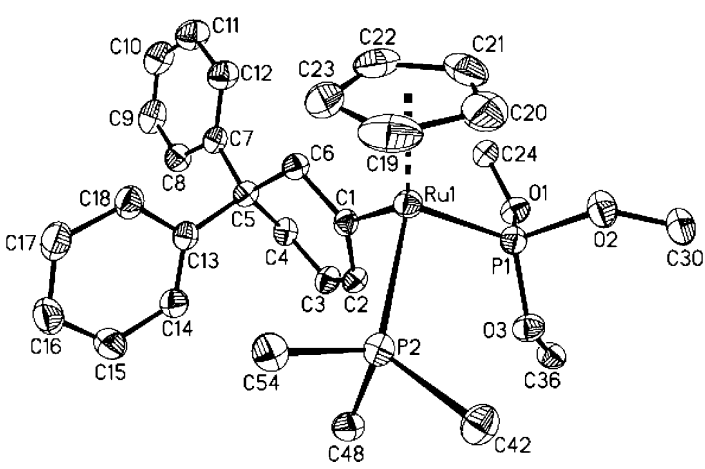

Figure 1. An ORTEP drawing of $\mathbf{5}$. Phenyl groups except the C(ipso) atoms on the phosphorus ligands have been omitted for clarity. Selected bond distances $(\mathrm{A})$ and angles $(\mathrm{deg}): \mathrm{Ru}(1)-\mathrm{C}(1), 1.957(4) ; \mathrm{Ru}(1)-\mathrm{P}(1)$, 2.2349(10); $\mathrm{Ru}(1)-\mathrm{P}(2), 2.3539(10) ; \mathrm{C}(1)-\mathrm{C}(2), 1.441(5) ; \mathrm{C}(2)-\mathrm{C}(3)$, 1.334(5); $\mathrm{C}(3)-\mathrm{C}(4), 1.486(5) ; \mathrm{C}(4)-\mathrm{C}(5), 1.532(5) ; \mathrm{C}(5)-\mathrm{C}(6), 1.550-$ (5); $\mathrm{C}(1)-\mathrm{C}(6), 1.531(5) ; \mathrm{C}(2)-\mathrm{C}(1)-\mathrm{C}(6), 113.2(3) ; \mathrm{C}(1)-\mathrm{C}(2)-\mathrm{C}(3)$, 124.3(3); $\mathrm{C}(2)-\mathrm{C}(3)-\mathrm{C}(4), 123.5(4) ; \mathrm{C}(1)-\mathrm{C}(6)-\mathrm{C}(5), 116.9(3)$

electronic as well as the steric effects of the ruthenium fragment. A series of 2D NMR studies, including COSY, HMQC, and HMBC experiments, unambiguously establish the structure of 4. Formation of $\mathbf{4}^{\prime}$ from $3 \mathbf{a}^{\prime}$, formally a migration of two phenyl substituents, could be interpreted by a metathesis process of two $\mathrm{C}=\mathrm{C}$ bonds (Scheme 1) involving a double cleavage of two unsaturated carbon-carbon bonds. ${ }^{7}$ Formation of $\mathbf{4}$ from 2a presumably proceeds via a similar pathway.

Reconstruction of Two $\mathbf{C}=\mathbf{C}$ Bonds. Unexpectedly, treatment of $\mathbf{4}$ with $\mathrm{MeOH}$ affords the carbene complex $\mathbf{5}$ with an unsaturated six-membered ring ligand as a reddish orange solid almost quantitatively (Scheme 1). Complex $\mathbf{5}$ is characterized by ${ }^{1} \mathrm{H},{ }^{31} \mathrm{P}\left\{{ }^{1} \mathrm{H}\right\},{ }^{13} \mathrm{C}\left\{{ }^{1} \mathrm{H}\right\}$ NMR, and $2 \mathrm{D}$ NMR spectroscopies and analytical data. In the ${ }^{13} \mathrm{C}\left\{{ }^{1} \mathrm{H}\right\}$ NMR spectrum of $\mathbf{5}$, the resonance corresponding to the $\mathrm{Ru}=\mathrm{C}_{\alpha}$ carbon atom appears at $\delta 321.4$ as a multiplet. In addition, two singlet resonances at $\delta 151.2$ and 135.5 are assigned to the olefinic carbon atoms of the six-membered ring on the basis of the ${ }^{1} \mathrm{H},{ }^{13} \mathrm{C}-\mathrm{HMQC}$ and ${ }^{1} \mathrm{H},{ }^{13} \mathrm{C}$-HMBC spectra. Complex $\mathbf{5}$ is also directly obtained via protonation of 2a with $\mathrm{HBF}_{4}$ in $\mathrm{MeOH}$ at $0{ }^{\circ} \mathrm{C}$. From a mechanistic point of view, it should be noted that direct intramolecular cyclization of the vinylidene with the terminal vinyl group in $\mathbf{4}$ should have a preference to give the unsaturated cyclic carbene complex A (Scheme 1), which is not observed. Treatment of complex $\mathbf{4}^{\prime}$ with $\mathrm{MeOH}$ also affords analogous carbene complex with much lower yield. No attempt was made to isolate the pure product for $\mathbf{4}^{\prime}$.

Slow diffusion of diethyl ether into a solution of $\mathbf{5}$ in dichloromethane allows collection of suitable single crystals for $\mathrm{X}$-ray diffraction study. An ORTEP diagram is shown in Figure 1 , and selected structure parameters are listed. The bond length of $\mathrm{Ru}(1)-\mathrm{C}(1)$ is $1.957(4) \AA$ showing a typical $\mathrm{Ru}=\mathrm{C}$ double bond, and the $\mathrm{C}(2)-\mathrm{C}(3)$ bond length is 1.334(5) $\AA$ showing a $\mathrm{C}=\mathrm{C}$ double bond character. The bond length of $\mathrm{C}(1)-\mathrm{C}(2)$ (1.441(5) $\AA$ ) is shorter than 1.531(5) $\AA$ of $\mathrm{C}(1)-\mathrm{C}(6)$, indicating delocalization of double bond character at $\mathrm{Ru}(1)-\mathrm{C}(1)-\mathrm{C}(2)-$ $\mathrm{C}(3)$.

The cyclization reaction of $\mathbf{4}$ in solvent other than $\mathrm{MeOH}$ gives an additional product. Treatment of complex $\mathbf{4}$ in aqueous acetone results in the formation of two products identified as $\mathbf{5}$ 


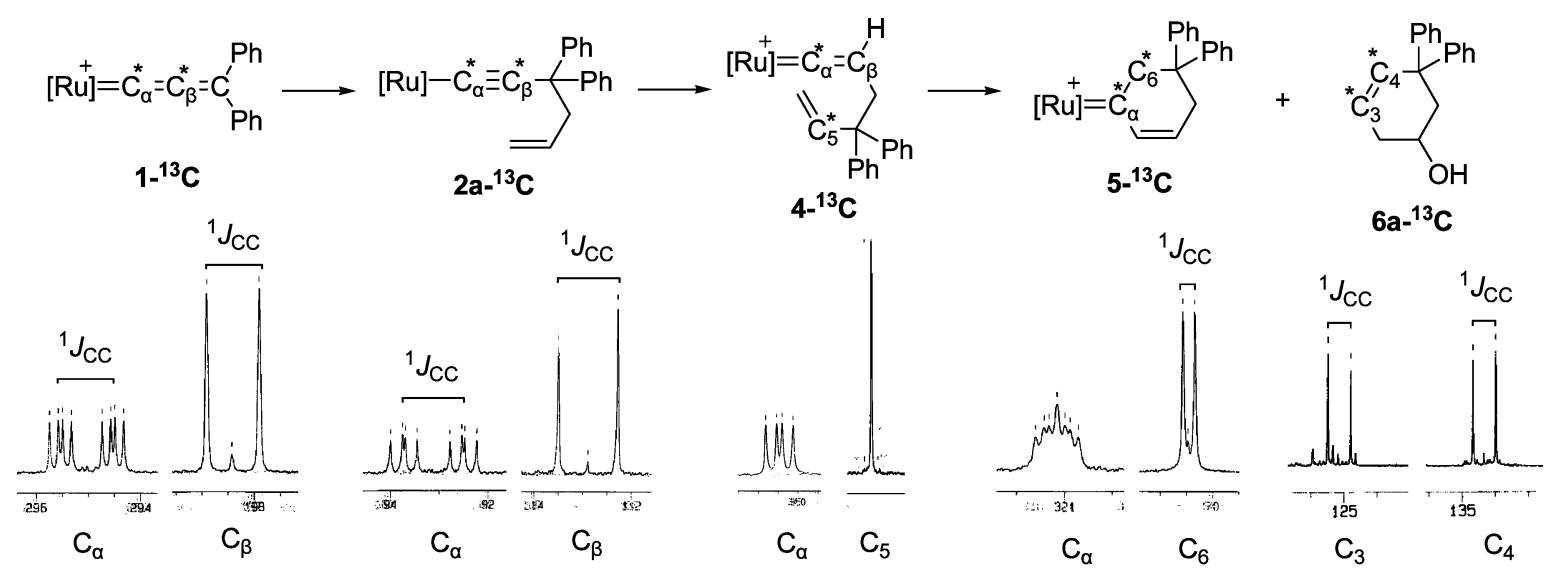

Figure 2. Resonances of enriched ${ }^{13} \mathrm{C}$ in the ${ }^{13} \mathrm{C}$ spectra of $1-{ }^{13} \mathrm{C}, \mathbf{2 a}^{-13} \mathrm{C}, 4^{13} \mathrm{C}, \mathbf{5}^{-13} \mathrm{C}$, and $\mathbf{6 a}^{-13} \mathrm{C}$.

and the organic cyclic alkene $\mathbf{6 a}$ in ca. 1:5 ratio (Scheme 1). ${ }^{10}$ Structural assignment of $\mathbf{6 a}$ is based on 2D NMR studies, including COSY, HMQC, and HMBC experiments and mass spectroscopy. In the ${ }^{1} \mathrm{H}$ NMR spectrum, the relatively downfield doublet resonance at $\delta 6.02$ is assigned to the olefinic proton near the gem-diphenyl groups. The multiplet resonance corresponding to the proton of $\mathrm{OCH}$ appears at $\delta 3.78$, demonstrating that $\mathrm{OCH}$ is directly bonded to two $\mathrm{CH}_{2}$ units. The anticipated product $\mathbf{B}$ shown in Scheme 1 is ruled out by the spectroscopic data. For the reaction in a mixture of $\mathrm{CH}_{2} \mathrm{Cl}_{2} / \mathrm{MeOH}(1: 1)$, the organic product $\mathbf{6 b}$ along with $\mathbf{5}$ was obtained. A similar outcome is obtained in the cyclization of $\mathbf{4}$ in $\mathrm{CH}_{2} \mathrm{Cl}_{2} / \mathrm{EtOH}$ (1:1), affording a mixture of $\mathbf{5}$ and $\mathbf{6 c}$ in a $3: 1$ ratio. Subjection of 4 to $\mathrm{CH}_{2} \mathrm{Cl}_{2} /{ }^{/} \mathrm{PrOH}(1: 1)$ also results in formation of $\mathbf{5}$ and 6d in a 3:1 ratio. For the reaction in $\mathrm{CH}_{2} \mathrm{Cl}_{2}$ in the presence of alcohol, lowering the concentration of alcohols $(\mathrm{MeOH}, \mathrm{EtOH}$, and ${ }^{i} \mathrm{PrOH}$ ) results in the formation of $\mathbf{6}$ as the major product (ca. 75\%). Gold(I)-catalyzed 5-endo hydroxy- or alkoxycyclization of 1,5-enynes provided access to functionalized fivemembered cyclopentenes where hydroxylation or alkoxylation took place at the external carbon of the ring skeletal. ${ }^{11}$ In contrast, Kozmin described an intramolecular formation of either $\mathrm{C}-\mathrm{O}$ or $\mathrm{C}-\mathrm{N}$ bonds in the skeletal framework of the ring in gold(I)-catalyzed synthesis of heterobicyclic alkenes as a result of the 6-endo-dig carbocyclizations of 1,5-enynes. ${ }^{12}$ The formation of $\mathbf{6}$ is similar to Kozmin's result.

${ }^{13}$ C-Labeling Experiment. To obtain information regarding the bonding relationship of the rearrangement of $\mathbf{3 a}$ to give 4 with subsequent transformation to $\mathbf{5}$ and $\mathbf{6}$, double labeled ${ }^{13} \mathrm{C}$ compounds are prepared. The ${ }^{13} \mathrm{C}$ double labeling at both $\mathrm{C}_{\alpha}$ and $\mathrm{C}_{\beta}$ for $\mathbf{2 a}^{\mathbf{2}}{ }^{\mathbf{1 3}} \mathbf{C}$ is readily achieved from alkylation of $\mathbf{1 a}-$ ${ }^{13} \mathbf{C}$. The ${ }^{13} \mathrm{C}$ NMR spectrum of ${ }^{2} \mathbf{a}-{ }^{\mathbf{1 3}} \mathbf{C}$ displays two intense resonances at $\delta 92.8$ and 112.9 with ${ }^{1} J_{\mathrm{C}-\mathrm{C}}=122.3 \mathrm{~Hz}$ assigned to the two enriched $\mathrm{C}_{\alpha}$ and $\mathrm{C}_{\beta}$ carbons, respectively, indicating direct connectivity (Figure 2). Treatment of $\mathbf{2} \mathbf{a}-{ }^{\mathbf{1 3}} \mathbf{C}$ with $\mathrm{HBF}_{4}$ exclusively affords $\mathbf{4 -}^{13} \mathbf{C}$, in which the two labeled ${ }^{13} \mathrm{C}$ atoms are at $\mathrm{C}_{\alpha}$ (a doublet of doublet resonance at $\delta 350.2$ with ${ }^{2} J_{\mathrm{C}-\mathrm{P}}$ $=21.0 \mathrm{~Hz}$ and ${ }^{2} J_{\mathrm{C}-\mathrm{P}^{\prime}}=14.0 \mathrm{~Hz}$ ) and at the internal vinyl $\mathrm{CH}$ unit (a singlet resonance at $\delta$ 143.6). Cleavage of two carbon atoms in the transformation of $\mathbf{2 a}$ to $\mathbf{4}$ is noticeably observed

(10) Nieto-Oberhuber, C.; Muñoz, M. P.; López, S.; Jiménez-Núñez, E.; Nevado, C.; Herrero-Gómez, E.; Raducan, M.; Echavarren, A. M. Chem.-Eur. J. 2006, 12, 1677.

(11) Buzas, A. K.; Istrate, F. M.; Gagosz, F. Angew. Chem., Int. Ed. 2007, 46, 1141.

(12) Zhang, L.; Kozmin, S. A. J. Am. Chem. Soc. 2005, 127, 6962.
Scheme 2

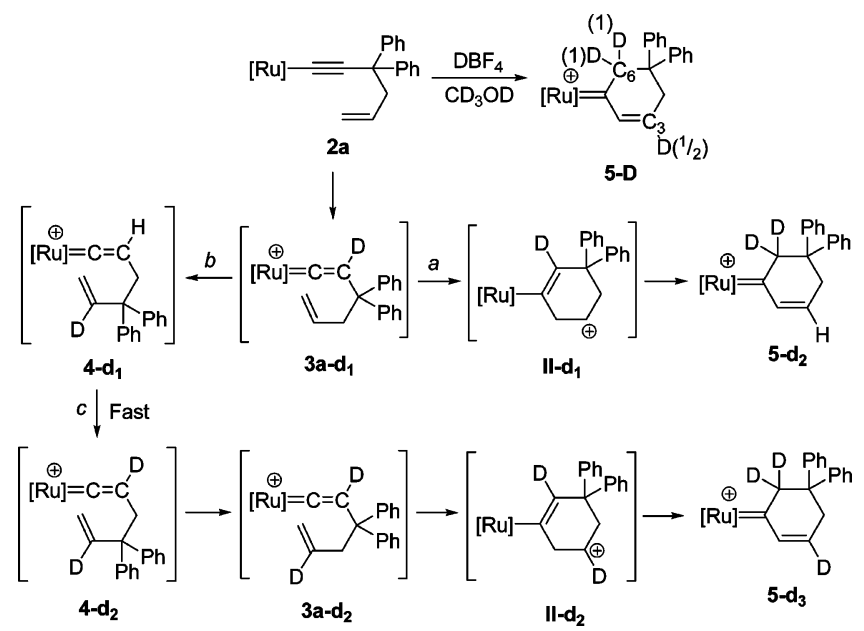

by the disappearance of a $\mathrm{C}-\mathrm{C}$ coupling between resonances of two enriched carbon atoms for $\mathbf{4 - 1 3}^{\mathbf{1 3}} \mathrm{C}$. As is also shown in Figure 2, reconstruction of the two labeled carbon atoms is revealed in the ${ }^{13} \mathrm{C}$ NMR spectrum showing two resonances at $\delta 321.1$ and 77.2 with ${ }^{1} J_{\mathrm{CC}}=23.8 \mathrm{~Hz}$ of the product ${ }^{5-13} \mathrm{C}$ obtained from ${ }^{4-13} \mathbf{C}$. The formation of alkoxy cyclic alkene 6 presumably also involves the same skeletal rearrangement. The ${ }^{13} \mathrm{C}$ NMR spectrum of $\mathbf{6 a}^{\mathbf{1 3}} \mathbf{C}$ obtained from $\mathbf{4 -}^{\mathbf{1 3}} \mathbf{C}$ in aqueous acetone shows two resonances at $\delta 134.4$ and 125.2 with ${ }^{1} J_{\mathrm{CC}}$ $=69.4 \mathrm{~Hz}$, indicating direct bonding of two ${ }^{13} \mathrm{C}$-enriched carbons. The formation of product $\mathbf{6}$ is thus proposed to proceed via skeletal rearrangement of $\mathbf{4}$ rather than a simple direct $\mathrm{C}-\mathrm{C}$ bond formation.

To further understand the mechanism of the formation of the unexpected finding of $\mathbf{5}$, we carry out the protonation of $\mathbf{2 a}$ using the deuterated tetrafluoroboric acid. The addition of excess amount of $\mathrm{DBF}_{4}$ to a methanol- $d_{4}$ solution of $\mathbf{2} \mathbf{a}$ produces a mixture marked as 5-D, which ${ }^{1} \mathrm{H}$ NMR displays deuterium contents of $100 \%$ and $50 \%$ at the $\mathrm{C}_{6}$ and $\mathrm{C}_{3}$ carbons, respectively (Scheme 2). The distribution of deuterium atoms in 5-D is supported by the ${ }^{1} \mathrm{H}$ NMR spectrum, which contains one $50 \%$ intensity of proton signal at $\delta 6.34$, and the results support the presence of skeletal rearrangement. Scheme 2 shows a plausible mechanism to account for the formation of 5-D. Deuteration of 2a generates $\mathbf{3 a - d _ { 1 }}$, which could form either the cyclization product $\mathbf{5}-\mathbf{d}_{\mathbf{2}}$ via pathway a or the metathesis product $\mathbf{4}-\mathbf{d}_{\mathbf{1}}$ via 
Scheme 3

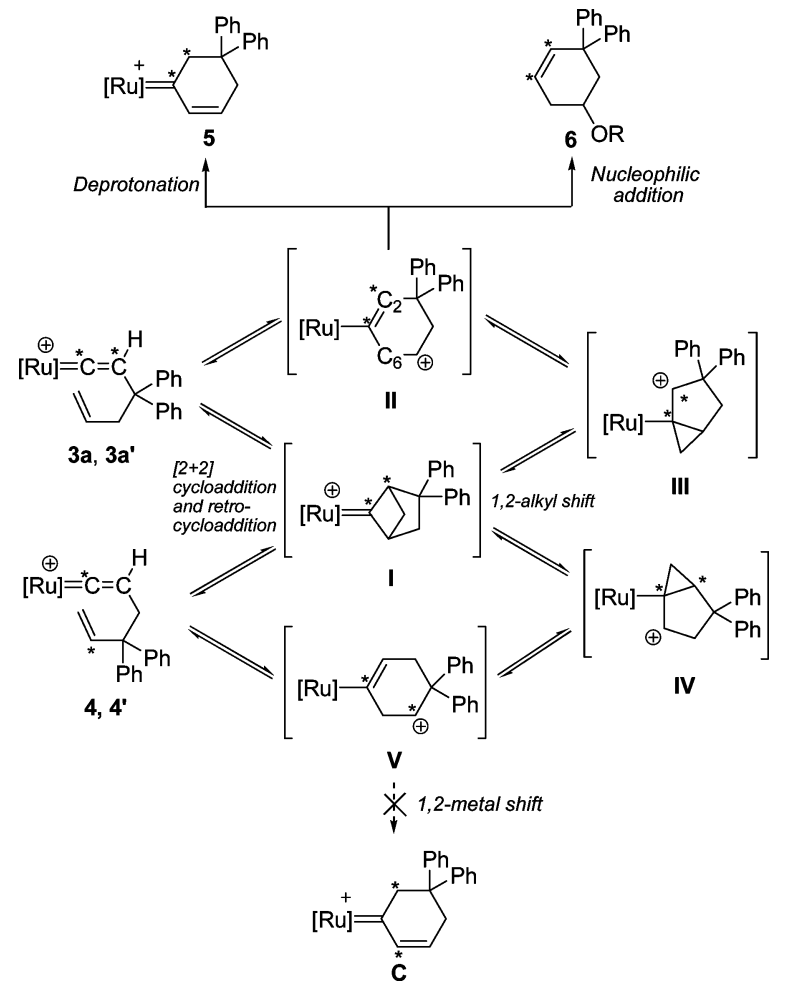

pathway b. Fast exchange of the vinylidene proton of $\mathbf{4}-\mathbf{d}_{\mathbf{1}}$ as shown in pathway c followed by retro-metathesis and cyclization results in $\mathbf{5}-\mathbf{d}_{\mathbf{3}}$ as the final product. Thus, the deuteration of $\mathbf{2 a}$ should yield 5-D: a mixture of $\mathbf{5}-\mathbf{d}_{\mathbf{2}}$ and $\mathbf{5}-\mathbf{d}_{\mathbf{3}}$. Presumably, the rate of proton exchange (pathway c) between the vinylidene proton and $\mathrm{CD}_{3} \mathrm{OD}$ should be much faster than the rate of the metathesis reaction (pathway b) and the cyclization (pathway a), which are probably approximately comparable. This labeling experiment also indicates that the transformation of $\mathbf{4}$ to $\mathbf{5}$ proceeds via the reversed metathesis reaction pathway to $\mathbf{3 a}$ first. Therefore, subjection of $\mathbf{4}$ in $\mathrm{CD}_{3} \mathrm{OD}$ should give $\mathbf{5}-\mathbf{d}_{\mathbf{3}}$ with complete D-labeling at $\mathrm{C}_{6}$ and $\mathrm{C}_{3}$ carbons (Scheme 2). As shown in Scheme 3, for the formation of $\mathbf{4}^{\prime}$, the double cleavage may proceed either via a $[2+2]$ cycloaddition of the two double bond in $\mathbf{3} \mathbf{a}^{\prime}$ leading to an unobserved species $\mathbf{I}$ followed by a retro-cycloaddition to give the observed product $^{13}$ or via formation of a bicyclic species III followed by 1,2-methylene shift. ${ }^{14}$ Our studies establish that the presence of a ruthenium vinylidene fragment is responsible for the novel skeletal reorganization to furnish another type of vinylidene complex possibly due to efficient stabilization of the cationic intermediate I. In the absence of the vinylidene fragment, the cyclization by gold-based catalyst afforded exclusively the [3.1.0] bicyclohexene. ${ }^{15}$

The formation of $\mathbf{5}$ shows an interesting ring closure that may be caused by two different pathways. The upper portion of Scheme 3 shows the skeletal rearrangement to give $\mathbf{5}$ with two labeled carbon atoms bound together. An alternative yet simpler

(13) Sun, J.; Conley, M. P.; Zhang, L.; Kozmin, S. A. J. Am. Chem. Soc. 2006, $128,9705$.

(14) (a) Alvarez, P.; Lastra, E.; Gimeno, J.; Bassetti, M.; Falvello, L. R. J. Am. Chem. Soc. 2003, 125, 2386. (b) Braña, P.; Gimeno, J.; Sordo, J. A. J. Org. Chem. 2004, 69, 2544

(15) Luzung, M. R.; Markham, J. P.; Toste, F. D. J. Am. Chem. Soc. 2004, 126, 10858 .

\section{Scheme 4}

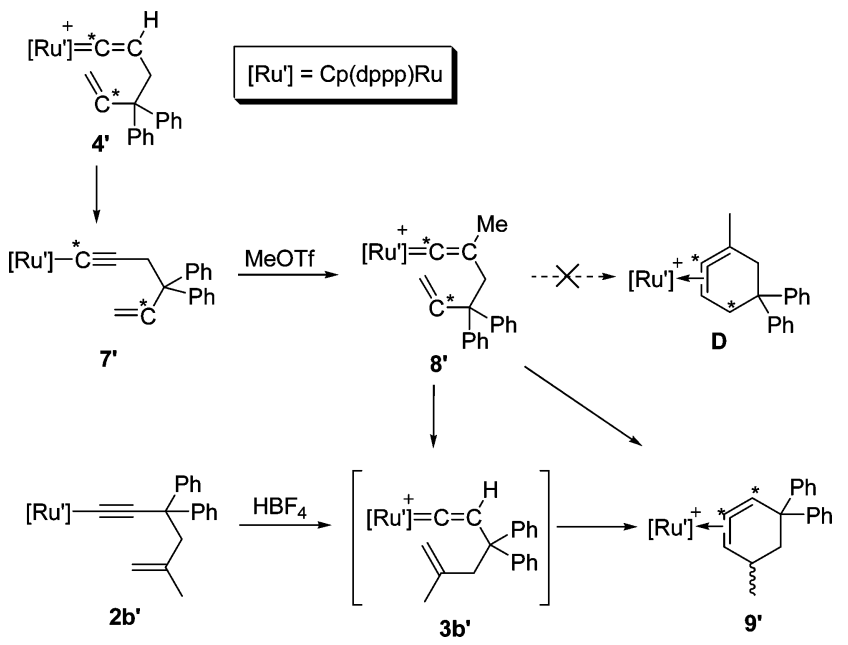

pathway is a $\mathrm{C}-\mathrm{C}$ bond formation followed by 1,2-metal migration to give $\mathbf{C}$ with two separated labeled atoms as shown in the lower part of Scheme 3. According to the ${ }^{13} \mathrm{C}$-labeling results, we proposed that product $\mathbf{5}$ is derived from $\mathbf{4}$ via a skeletal rearrangement. Transformation of $\mathbf{4}$ to $\mathbf{5}$ could be interpreted by a reversed process of formation of $\mathbf{4}$ giving back 3a via the metathesis route followed by an intramolecular attack of the terminal olefin to $\mathrm{C}_{\alpha}$ generating the cation II (Scheme 3) containing a six-membered ring. Deprotonation at $\mathrm{C}_{6}$ (see Scheme 3) followed by protonation at $\mathrm{C}_{2}$ leads to the product 5. Scheme 3 also shows an alternative pathway sequentially via $\mathbf{V}, \mathbf{I V}, \mathbf{I}$, then the cation III, which also undergoes deprotonation and protonation to give the observed product $\mathbf{5}$.

Formation of the alkoxy-cyclic alkene products $\mathbf{6}$ can be rationalized using the mechanistic analysis presented also in Scheme 3. The transformation of complex $\mathbf{4}$ to the cationic species II is followed by a nucleophilic attack of an alkoxy group with subsequent cleavage of the ruthenium-cyclic alkene bond producing compound $\mathbf{6}$ and ruthenium species, which is not identified.

A Further Example. Two neutral $\sigma$-alkynyl complexes $[\mathrm{M}]-\mathrm{C} \equiv \mathrm{CC}(\mathrm{Ph})_{2} \mathrm{CH}_{2} \mathrm{C}(\mathrm{Me})=\mathrm{CH}_{2}\left(\mathbf{2} \mathbf{b},[\mathrm{M}]=[\mathrm{Ru}]\right.$ and $\mathbf{2} \mathbf{b}^{\prime}$, $\left.[\mathrm{M}]=\left[\mathrm{Ru}^{\prime}\right]\right)$ are synthesized from the reactions of the Grignard reagent $\mathrm{CH}_{2}=\mathrm{C}(\mathrm{Me}) \mathrm{CH}_{2} \mathrm{MgCl}$ with $\mathbf{1}$ and $\mathbf{1}^{\prime}$, respectively. ${ }^{9}$ With only an additional methyl group on the internal carbon of the terminal vinyl functionality, complex $\mathbf{2} \mathbf{b}^{\prime}$, upon protonation, is converted to complex $\mathbf{9}^{\prime}$ containing a cyclic $\pi$-allenyl ligand (Scheme 4). ${ }^{7,16}$ A mixture of diastereomers of 9 is also obtained directly and instantaneously from protonation of $\mathbf{2 b}$. In such a cyclization, no $\mathrm{C}-\mathrm{C}$ bond cleavage was observed. We are surprised to observe the completely different reactivity between the allyl- and 2-methylallyl-substituted vinylidene complexes. It is therefore interesting to explore the chemical reactivity of similar metal vinylidene complex containing a methyl group, instead of a hydrogen, at $\mathrm{C}_{\beta}$, that is, $\left[\left[\mathrm{Ru}^{\prime}\right]=\mathrm{C}=\mathrm{C}(\mathrm{Me})\right.$ $\left.\mathrm{CH}_{2} \mathrm{C}(\mathrm{Ph})_{2} \mathrm{CH}=\mathrm{CH}_{2}\right]\left[\mathrm{BF}_{4}\right]$. For this reason, the following experiments shown in Scheme 4 are carried out. Deprotonation of $\mathbf{4}^{\prime}$ generates the acetylide complex $\mathbf{7}^{\prime}$. Methylation of $\mathbf{7}^{\prime}$ using methyl triflate takes place at $\mathrm{C}_{\beta}$, giving the unstable vinylidene complex $\mathbf{8}^{\prime}$, which undergoes a cyclization to also generate $\mathbf{9}^{\prime}$.

(16) Cadierno, V.; Conejero, S.; Díez, J.; Gamasa, M. P.; Gimeno, J.; GarcíaGranda, S. Chem. Commun. 2003, 840. 


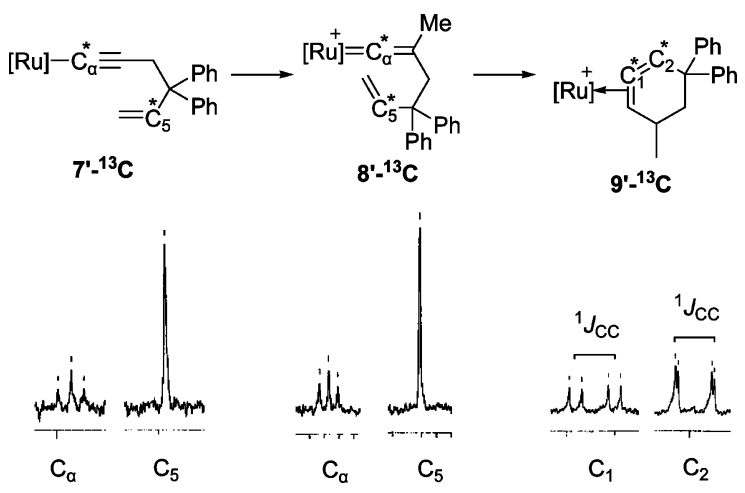

Figure 3. Signal of resonances of enriched ${ }^{13} \mathrm{C}$ in the ${ }^{13} \mathrm{C}$ spectra of $\mathbf{7}^{\prime}$ ${ }^{13} \mathrm{C}, 8^{\prime}{ }^{13} \mathrm{C}$, and $9^{\prime}-{ }^{13} \mathrm{C}$.

\section{Scheme 5}

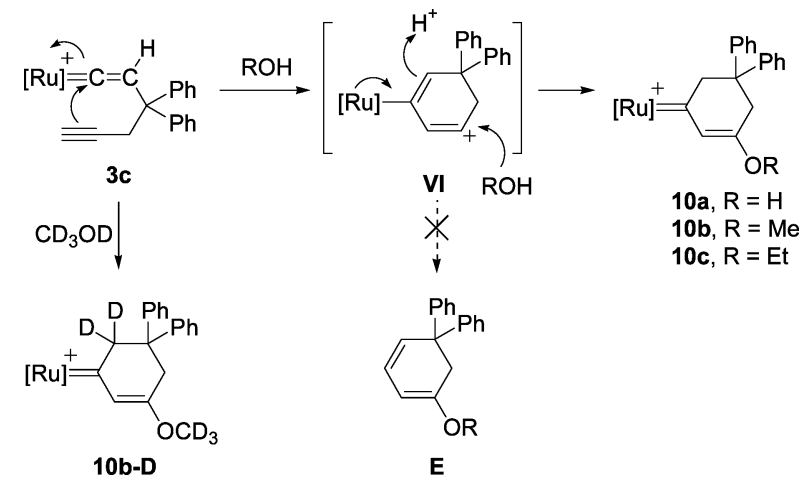

The anticipated complex $\mathbf{D}$ with two separated labeled carbon atoms shown in Scheme 4 is not observed.

The ${ }^{13} \mathrm{C}$-labeling experiment also elucidates the mechanism of such a ring closure process. Using $25 \%$ doubly ${ }^{13} \mathrm{C}$-enriched sample, separation of two ${ }^{13} \mathrm{C}$-labeled atoms in $\mathbf{4}^{\prime}-{ }^{13} \mathrm{C}$ obtained from $3 \mathbf{a}^{\prime} \mathbf{- 1}^{13} \mathbf{C}$ is confirmed by the disappearance of the ${ }^{1} J_{\mathrm{C}-\mathrm{C}}$ (Figure 3). Deprotonation of $\mathbf{4}^{\prime}-{ }^{\mathbf{1 3}} \mathbf{C}$ gives $\mathbf{7}^{\prime}-{ }^{\mathbf{1 3}} \mathbf{C}$, and then methylation of $\mathbf{7}^{\prime}-{ }^{13} \mathbf{C}$ at $\mathrm{C}_{\beta}$ yields the vinylidene complex $\mathbf{8}^{\prime}$ ${ }^{13} \mathrm{C}$. A retro-metathesis process establishing the original $\mathrm{C}-\mathrm{C}$ bond of the two enriched ${ }^{13} \mathrm{C}$ atoms is followed by a cyclization of the resulting vinylidene ligand giving complex $9^{\prime}-{ }^{13} \mathbf{C}$. As mentioned before, the cyclic allenyl complex $\mathbf{9}^{\prime}$ can also be readily prepared from the vinylidene complex $\mathbf{2} \mathbf{b}^{\prime} .{ }^{13} \mathrm{C}$-labeling studies clearly reveal the reestablishment of the $\mathrm{C}=\mathrm{C}$ double bond again in the transformation of $\mathbf{8}^{\prime}$ to $\mathbf{9}^{\prime}$. The ${ }^{13} \mathrm{C}-{ }^{13} \mathrm{C}$ coupling constant of $81.6 \mathrm{~Hz}$ of $\mathbf{9}^{\prime}{ }^{13} \mathbf{C}$ as shown in Figure 3 falls in the range of ${ }^{1} J_{\mathrm{C}-\mathrm{C}}$ coupling.

Cyclization of the Alkynyl Vinylidene Moiety. The vinylidene complex $\mathbf{3 c}$ containing a terminal alkynyl group could also be obtained from alkylation of $\mathbf{1}$ using $\mathrm{HC} \equiv \mathrm{CCH}_{2} \mathrm{MgBr}$ followed by protonation. Treatment of $\mathbf{3 c}$ with aqueous acetone gives the cyclic carbene complex 10a in high yield; see Scheme 5. The structure of 10a is established by its ${ }^{1} \mathrm{H},{ }^{13} \mathrm{C}$, and $2 \mathrm{D}$ NMR spectra. In the ${ }^{13} \mathrm{C}$ NMR spectrum, the broad resonance at $\delta 300.5$ is assigned to the carbene carbon. In 10a with two different phosphorus ligands, the restricted rotation of the $\mathrm{Ru}=$ $\mathrm{C}$ bond caused by the presence of the gem-diphenyl group generates diastereoisomers making the $\mathrm{C} \alpha$ carbon resonate as a broad peak. The same synthetic strategy is used to obtain other cyclic carbene complexes $\mathbf{1 0 b}$ and $\mathbf{1 0 c}$ containing methoxy and ethoxy functionalities from the reaction of $\mathbf{3 c}$ with $\mathrm{MeOH}$ and EtOH, respectively. In the presence of $d_{4}$-methanol, complex
10b-D with a completely deuterated methylene group at $\mathrm{C}_{\beta}$ in the ring is obtained. The presence of two deuterium atoms in the six-membered ring is consistent with facile protonation of the vinyl carbon in VI shown in Scheme 5. The anticipated cyclic organic compound $\mathbf{E}$ via a demetallation process was not observed. However, nucleophilic cyclization of enediynes catalyzed by $\left[\mathrm{TpRu}\left(\mathrm{PPh}_{3}\right)\left(\mathrm{CH}_{3} \mathrm{CN}\right)_{2}\right]\left[\mathrm{PF}_{6}\right]$ resulting in aromatized product similar to $\mathbf{E}$ has been reported by Liu. ${ }^{17}$

\section{Conclusion}

In summary, we report that the protonation of $\mathbf{2} \mathbf{a}$ in $\mathrm{Et}_{2} \mathrm{O}$ affords $\mathbf{4}$ via an unusual metathesis process of the terminal vinyl group and the $\mathrm{C}=\mathrm{C}$ of the vinylidene group of the proposed intermediate complex 3a. Two $\mathrm{C}=\mathrm{C}$ bonds are reconstructed during the transformation of $\mathbf{4}$ in alcohols to $\mathbf{5}$ and $\mathbf{6}$, which involves a skeletal rearrangement followed by a $\mathrm{C}-\mathrm{C}$ bond formation giving cyclic compounds, and the results are supported by ${ }^{13} \mathrm{C}$ - and ${ }^{2} \mathrm{H}$-labeling experiments. However, protonation of the acetylide complex $\mathbf{2} \mathbf{b}^{\prime}$ with a 2-methylallyl group readily affords the cyclic allenyl complex $\mathbf{9}^{\prime}$. Interestingly, reestablishment of two $\mathrm{C}=\mathrm{C}$ double bonds could also be observed in the vinylidene complex with a methyl and the same butenyl group at $\mathrm{C}_{\beta}$, giving also $\mathbf{9}^{\prime}$. Metathesis of two $\mathrm{C}=\mathrm{C}$ bonds takes place for the transformation of $\mathbf{3} \mathbf{a}^{\prime}$ to $\mathbf{4}^{\prime}$. Deprotonation of $\mathbf{4}^{\prime}$ yields the acetylide complex $\mathbf{7}^{\prime}$, which undergoes methylation at $\mathrm{C}_{\beta}$ to give the vinylidene product $\mathbf{8}^{\prime}$. The retro-metathesis process of $\mathbf{8}^{\prime}$ establishing two original $\mathrm{C}=\mathrm{C}$ bonds in $\mathbf{3} \mathbf{a}^{\prime}$ is followed by a cyclization of the resulting vinylidene ligand also producing 9'. ${ }^{13} \mathrm{C}$-labeling studies clearly reveal reestablishment of the $\mathrm{C}=$ $\mathrm{C}$ double bond in the transformation of $\mathbf{8}^{\prime}$ to $\mathbf{9}^{\prime}$. Importantly, the vinylidene moiety is uniquely responsible for the novel mechanism of the cycloisomerization, which is proposed to involve a regiospecific [2+2] cycloaddition of two double bonds in 4 or $\mathbf{4}^{\prime}$, or a cyclization of ruthenium vinylidene 4 or $\mathbf{4}^{\prime}$ to give a nonclassical ion followed by a cascade of 1,2-alkyl shift to form the cyclobutylidene intermediate $\mathbf{I}$.

\section{Experimental Section}

General Procedures. The manipulations were performed under an atmosphere of dry nitrogen using a vacuum-line and standard Schlenk techniques. Solvents were dried by standard methods and distilled under nitrogen before use. All reagents were obtained from commercial suppliers (TMS ${ }^{13} \mathrm{C} \equiv{ }^{13} \mathrm{CH}$ from Isotec) and used without further purification. The complexes $\mathrm{Cp}\left(\mathrm{PPh}_{3}\right)_{2} \mathrm{RuCl},{ }^{18 \mathrm{a}} \mathrm{Cp}\left(\mathrm{P}(\mathrm{OPh})_{3}\right)\left(\mathrm{PPh}_{3}\right)$ $\mathrm{RuCl},{ }^{18 \mathrm{~b}}$ and $\mathrm{Cp}(\mathrm{dppp}) \mathrm{RuCl}^{18 \mathrm{c}}$ were prepared by literature methods. The $\mathrm{C}$ and $\mathrm{H}$ analyses were carried out with a Perkin-Elmer 2400 microanalyzer. Mass spectra (FAB) were recorded using a JEOL SX102A spectrometer; 3-nitrobenzyl alcohol (NBA) was used as the matrix. NMR spectra were recorded on a Bruker AC-300 instrument at $300 \mathrm{MHz}\left({ }^{1} \mathrm{H}\right), 121.5 \mathrm{MHz}\left({ }^{31} \mathrm{P}\right)$, or $75.4 \mathrm{MHz}\left({ }^{13} \mathrm{C}\right)$ using $\mathrm{SiMe}_{4}$ or $85 \% \mathrm{H}_{3} \mathrm{PO}_{4}$ as a standard or an Avance 500 FT-NMR spectrometer.

Synthesis of Ruthenium Vinylidene Complexes 4 and $4^{\prime}$. [[Ru $]=$ $\left.\mathbf{C}=\mathbf{C H C H} \mathbf{H}_{2} \mathbf{C}(\mathbf{P h})_{2} \mathbf{C H}=\mathbf{C H}_{2}\right]\left[\mathbf{B F}_{4}\right]$ (4). A solution of $\mathrm{HBF}_{4} \cdot \mathrm{Et}_{2} \mathrm{O}$ $(0.200 \mathrm{~mL}, 1.0 \mathrm{M})$ in diethyl ether was added dropwise at $-20{ }^{\circ} \mathrm{C}$ to a stirred solution of $\mathbf{2 a}(0.100 \mathrm{~g}, 0.103 \mathrm{~mol})$ in $20 \mathrm{~mL}$ of diethyl ether. Immediately, an insoluble solid formed, but the addition was continued until no solid was further formed. The solution was decanted, and the orange solid 4 was washed with diethyl ether $(3 \times 5 \mathrm{~mL})$ and dried in

(17) Odedra, A.; Wu, C. J.; Pratap, T. B.; Huang, C. W.; Ran, Y. F.; Liu, R. S. J. Am. Chem. Soc. 2005, 127, 3406.

(18) (a) Bruce, M. I.; Wallis, R. C. Aust. J. Chem. 1979, 32, 1471. (b) Joslin, F. L.; Mague, J. T.; Roundhill, D. M. Organometallics 1991, 10, 521. (c) Oshima, N.; Suzuki, H.; Moro-Oka, Y. Chem. Lett. 1984, 1161. 
vacuo. Yield: $0.108 \mathrm{~g}(95 \%) .{ }^{1} \mathrm{H}$ NMR $\left(\delta, \mathrm{CDCl}_{3}\right)$ : 7.53-6.69 (m, $40 \mathrm{H}, \mathrm{Ph}), 6.28\left(\mathrm{dd},{ }^{3} J_{\mathrm{HH}}=17.4 \mathrm{~Hz},{ }^{3} J_{\mathrm{HH}}=10.8 \mathrm{~Hz}, 1 \mathrm{H},-\mathrm{CH}=\mathrm{CH}_{2}\right)$, $5.21\left(\mathrm{~d},{ }^{3} J_{\mathrm{HH}}=10.8,1 \mathrm{H},=\mathrm{CH}_{2}\right), 5.02(\mathrm{~s}, 5 \mathrm{H}, \mathrm{Cp}), 4.55\left(\mathrm{~d},{ }^{3} J_{\mathrm{HH}}=\right.$ $\left.17.4 \mathrm{~Hz}, 1 \mathrm{H},=\mathrm{CH}_{2}\right), 3.78\left(\mathrm{~m}, 1 \mathrm{H},=\mathrm{C}_{\beta} \mathrm{H}\right), 2.68\left(\mathrm{dd},{ }^{2} J_{\mathrm{HH}}=13.9 \mathrm{~Hz}\right.$, $\left.{ }^{3} J_{\mathrm{HH}}=5.8 \mathrm{~Hz}, 1 \mathrm{H}, \mathrm{C}_{\gamma} H_{2}\right), 2.41\left(\mathrm{dd},{ }^{2} J_{\mathrm{HH}}=13.9 \mathrm{~Hz},{ }^{3} J_{\mathrm{HH}}=5.8 \mathrm{~Hz}\right.$, $\left.1 \mathrm{H}, \mathrm{C}_{\gamma} H_{2}\right) .{ }^{13} \mathrm{C}\left\{{ }^{1} \mathrm{H}\right\} \operatorname{NMR}\left(\delta, \mathrm{CD}_{2} \mathrm{Cl}_{2}\right): 351.1\left(\mathrm{dd},{ }^{2} J_{\mathrm{PC}}=18.6 \mathrm{~Hz}\right.$, $\left.{ }^{2} J_{\mathrm{PC}}=15.1 \mathrm{~Hz}, \mathrm{C}_{\alpha}\right), 149.5-126.4(\mathrm{Ph}+=C \mathrm{H}), 119.2\left(\mathrm{C}_{\beta}\right), 115.6$ $\left(=\mathrm{CH}_{2}\right), 93.4(\mathrm{Cp}), 51.3(\mathrm{C}), 31.0\left(\mathrm{CH}_{2}\right) .{ }^{31} \mathrm{P}\left\{{ }^{1} \mathrm{H}\right\} \mathrm{NMR}\left(\delta, \mathrm{CDCl}_{3}\right)$ : $131.7\left(\mathrm{~d},{ }^{2} J_{\mathrm{PP}}=47.3 \mathrm{~Hz}\right), 46.5\left(\mathrm{~d},{ }^{2} J_{\mathrm{PP}}=47.3 \mathrm{~Hz}\right) . \mathrm{MS}(\mathrm{FAB}+) \mathrm{m} / \mathrm{z}$ : $971.3\left(\mathrm{M}^{+}\right), 739.3\left(\mathrm{CpRuPPh}{ }_{3} \mathrm{P}(\mathrm{OPh})_{3}\right)$. Anal. Calcd for $\mathrm{C}_{59} \mathrm{H}_{51} \mathrm{BF}_{4} \mathrm{O}_{3} \mathrm{P}_{2^{-}}$ Ru: C, 66.99; H, 4.86. Found: C, 67.11; H, 4.77.

$\left[\left[\mathrm{Ru}^{\prime}\right]=\mathbf{C}=\mathrm{CHCH}_{2} \mathbf{C}(\mathbf{P h})_{2} \mathbf{C H}=\mathbf{C H}_{2}\right]\left[\mathrm{BF}_{4}\right]\left(\mathbf{4}^{\prime}\right)$. A Schlenk flask was charged with $3 \mathbf{a}^{\prime}(0.10 \mathrm{~g}, 0.11 \mathrm{mmol})$ and $\mathrm{CH}_{2} \mathrm{Cl}_{2}(15 \mathrm{~mL})$, and the mixture was stirred for $2 \mathrm{~h}$. The solvent was reduced to $5 \mathrm{~mL}$ under vacuum, and then the residue mixture was added to $30 \mathrm{~mL}$ of diethyl ether. The chestnut brown precipitate thus formed was filtered and washed with diethyl ether $(2 \times 5 \mathrm{~mL})$ and dried under vacuum to give $4^{\prime}(0.09 \mathrm{~g}$, yield $90 \%) .{ }^{1} \mathrm{H}$ NMR $\left(\delta, \mathrm{CDCl}_{3}\right): 7.42-7.05(\mathrm{~m}, 30 \mathrm{H}, \mathrm{Ph})$, $6.33\left(\mathrm{dd},{ }^{3} J_{\mathrm{HH}}=17.5 \mathrm{~Hz},{ }^{3} J_{\mathrm{HH}}=10.8 \mathrm{~Hz}, 2 \mathrm{H},=\mathrm{CH}_{2}\right), 5.20\left(\mathrm{~d},{ }^{3} J_{\mathrm{HH}}\right.$ $\left.=10.8 \mathrm{~Hz}, 1 \mathrm{H},=\mathrm{CH}_{2}\right), 5.18(\mathrm{~s}, 5 \mathrm{H}, \mathrm{Cp}), 4.77\left(\mathrm{~d},{ }^{3} J_{\mathrm{HH}}=17.5 \mathrm{~Hz}, 1 \mathrm{H}\right.$, $\left.=\mathrm{CH}_{2}\right), 4.21\left(\mathrm{t},{ }^{3} J_{\mathrm{HH}}=7.8 \mathrm{~Hz}, 1 \mathrm{H},=\mathrm{C}_{\beta} \mathrm{H}\right), 3.13\left(\mathrm{~d},{ }^{3} J_{\mathrm{HH}}=7.8 \mathrm{~Hz}\right.$, $\left.2 \mathrm{H}, \mathrm{CH}_{2}\right), 2.67-1.75(\mathrm{~m}, 6 \mathrm{H}, \mathrm{dppp}) .{ }^{13} \mathrm{C}\left\{{ }^{1} \mathrm{H}\right\} \mathrm{NMR}\left(\delta, \mathrm{CD}_{2} \mathrm{Cl}_{2}\right): 343.2$ $\left(\mathrm{t},{ }^{2} J_{\mathrm{PC}}=16.0 \mathrm{~Hz}, \mathrm{C}_{\alpha}\right), 145.5-126.5(\mathrm{~m}, \mathrm{Ph}), 143.4\left(\mathrm{~s},-\mathrm{CH}=\mathrm{CH}_{2}\right)$, $114.8\left(\mathrm{~s},=\mathrm{CH}_{2}\right), 108.0\left(\mathrm{~s}, \mathrm{C}_{\beta}\right), 92.6(\mathrm{~s}, \mathrm{Cp}), 53.7\left(\mathrm{~s}, \mathrm{C}_{\gamma}\right), 29.7\left(\mathrm{~s}, \mathrm{CH}_{2}\right)$, 26.7-20.3 (m, dppp). ${ }^{31} \mathrm{P}\left\{{ }^{1} \mathrm{H}\right\}$ NMR $\left(\delta, \mathrm{CDCl}_{3}\right)$ : 36.6. Anal. Calcd for $\mathrm{C}_{50} \mathrm{H}_{47} \mathrm{BF}_{4} \mathrm{P}_{2} \mathrm{Ru}$ : C, 66.89; H, 5.28. Found: C, 66.74; H, 5.37.

Synthesis of Cyclic Carbene Complex 5. Method 1: A solution of $\mathrm{HBF}_{4} \cdot \mathrm{Et}_{2} \mathrm{O}$ in diethyl ether was added dropwise to a solution of $\mathbf{2 a}$ $(0.100 \mathrm{~g}, 0.103 \mathrm{~mol})$ in methanol $(20 \mathrm{~mL})$ at $0{ }^{\circ} \mathrm{C}$. The resulting solution was further stirred for $1 \mathrm{~h}$ at room temperature and then dried under vacuum. The resulting powder was washed with diethyl ether $(3 \times 5$ $\mathrm{mL})$ and was identified as $5(0.104 \mathrm{~g}, 92 \%)$. Method 2: A solution of complex 4 (0.100 g, $0.095 \mathrm{mmol})$ in $\mathrm{MeOH}$ was stirred for $1 \mathrm{~h}$ at room temperature under nitrogen. The resulting solution was dried under vacuum to give complex 5 quantitatively. ${ }^{1} \mathrm{H} \mathrm{NMR}\left(\delta, \mathrm{CDCl}_{3}\right)$ : $7.36-$ $6.68\left(\mathrm{~m}, 41 \mathrm{H}, \mathrm{Ph}\right.$ and $\left.=\mathrm{C}_{\beta} \mathrm{H}\right), 6.31\left(\mathrm{br}, 1 \mathrm{H},=\mathrm{C}_{\gamma} \mathrm{H}\right), 5.12(\mathrm{~s}, 5 \mathrm{H}, \mathrm{Cp})$, $4.76\left(\mathrm{~d},{ }^{2} J_{\mathrm{HH}}=18.1 \mathrm{~Hz}, 1 \mathrm{H}, \mathrm{C}_{\alpha} \mathrm{CH}_{2}\right), 2.73\left(\mathrm{~d},{ }^{2} J_{\mathrm{HH}}=20.0 \mathrm{~Hz}, 1 \mathrm{H}\right.$, $\left.\mathrm{C}_{\delta} \mathrm{H}_{2}\right), 2.68\left(\mathrm{~d},{ }^{2} J_{\mathrm{HH}}=18.1 \mathrm{~Hz}, 1 \mathrm{H}, \mathrm{C}_{\alpha} \mathrm{CH}_{2}\right), 1.75\left(\mathrm{~d},{ }^{2} J_{\mathrm{HH}}=20.0 \mathrm{~Hz}\right.$, $\left.{ }^{4} J_{\mathrm{HH}}=5.5 \mathrm{~Hz}, 1 \mathrm{H}, \mathrm{C}_{\delta} \mathrm{H}_{2}\right) \cdot{ }^{13} \mathrm{C}\left\{{ }^{1} \mathrm{H}\right\} \mathrm{NMR}\left(\delta, \mathrm{CDCl}_{3}\right): 321.4\left(\mathrm{br}, \mathrm{C}_{\alpha}\right)$, $151.2\left(\mathrm{C}_{\beta}\right), 151.1-120.1(\mathrm{Ph}), 135.5\left(\mathrm{C}_{\gamma}\right), 94.7(\mathrm{Cp}), 70.6\left(\mathrm{C}_{\alpha} \mathrm{CH}_{2}\right)$, $47.5(\mathrm{C}), 39.2\left(\mathrm{C}_{\delta}\right) \cdot{ }^{31} \mathrm{P}\left\{{ }^{1} \mathrm{H}\right\} \mathrm{NMR}\left(\delta, \mathrm{CDCl}_{3}\right): 135.2\left(\mathrm{~d},{ }^{2} J_{\mathrm{PP}}=54.2\right.$ $\left.\mathrm{Hz}, \mathrm{P}(\mathrm{OPh})_{3}\right), 51.2\left(\mathrm{~d},{ }^{2} J_{\mathrm{PP}}=54.2 \mathrm{~Hz}, \mathrm{PPh}_{3}\right)$. MS $(\mathrm{FAB}+) \mathrm{m} / \mathrm{z}: 971.3$ $\left(\mathrm{M}^{+}\right), 739.3\left(\mathrm{CpRuPPh}{ }_{3} \mathrm{P}(\mathrm{OPh})_{3}\right)$. Anal. Calcd for $\mathrm{C}_{59} \mathrm{H}_{51} \mathrm{BF}_{4} \mathrm{O}_{3} \mathrm{P}_{2} \mathrm{Ru}$ : C, 66.99; H, 4.86. Found: C, 66.83; H, 4.85.

General Procedure for the Synthesis of 5-Alkoxy-3,3-diphenylcyclohex-1-ene (6). A solution of $4(0.100 \mathrm{~g}, 0.095 \mathrm{mmol})$ in $\mathrm{CH}_{2} \mathrm{Cl}_{2}$ $(5 \mathrm{~mL})$ was treated with aqueous acetone $(\mathbf{6 a})$ or alcohol $(0.2 \mathrm{~mL}, \mathbf{6 b}$, $\mathbf{6 c}$, and $\mathbf{6 d}$ ), and the resulting solution was stirred for $24 \mathrm{~h}$ at room temperature under nitrogen. After evaporation of the solvent, the residue was identified as the mixture of $\mathbf{5}$ and alkoxy cyclic alkene $\mathbf{6}$, which was extracted twice with $10 \mathrm{~mL}$ of hexanes and dried in vacuo to give the crude $\mathbf{6}$. The crude compound was purified by flash chromatography (silica gel, hexanes/EtOAc 20/1) to afford 6.

5,5-Diphenylcyclohex-3-enol (6a). Yield: $0.019 \mathrm{~g}(84 \%) .{ }^{1} \mathrm{H}$ NMR $\left(\delta, \mathrm{CDCl}_{3}\right): 7.31-6.87(\mathrm{~m}, 10 \mathrm{H}, \mathrm{Ph}), 6.02\left(\mathrm{~d},{ }^{2} J_{\mathrm{HH}}=10.0 \mathrm{~Hz}, 1 \mathrm{H}\right.$, $\left.\mathrm{CH}_{2} \mathrm{CH}=\mathrm{CH}\right), 5.68\left(\mathrm{~m}, 1 \mathrm{H}, \mathrm{CH}_{2} \mathrm{CH}=\mathrm{CH}\right), 3.80(\mathrm{br} \mathrm{s}, 1 \mathrm{H}, \mathrm{OH}), 3.78$ $(\mathrm{m}, 1 \mathrm{H}, \mathrm{OCH}), 2.55\left(\mathrm{dd},{ }^{2} J_{\mathrm{HH}}=12.3 \mathrm{~Hz}, 1 \mathrm{H}, \mathrm{CH}_{2}\right), 2.30-2.21(\mathrm{~m}$, $\left.2 \mathrm{H}, \mathrm{CH}_{2}\right), 1.97\left(\mathrm{~m}, 1 \mathrm{H}, \mathrm{CH}_{2}\right) .{ }^{13} \mathrm{C}\left\{{ }^{1} \mathrm{H}\right\}$ NMR $\left(\delta, \mathrm{CDCl}_{3}\right): 134.4\left(\mathrm{CH}_{2-}\right.$ $\mathrm{CH}=\mathrm{CH}), 125.2\left(\mathrm{CH}_{2} \mathrm{CH}=\mathrm{CH}\right), 149.5-120.4(\mathrm{~m}, \mathrm{Ph}), 64.6(\mathrm{CHOH})$, $51.0(\mathrm{C}), 45.5\left(\mathrm{CH}_{2}\right), 35.1\left(\mathrm{CH}_{2}\right)$. EI-MS $\mathrm{m} / z$ (\%, relative intensity): $250(\mathrm{M}+, 27 \%)$. Anal. Calcd for $\mathrm{C}_{18} \mathrm{H}_{18} \mathrm{O}: \mathrm{C}, 86.36 ; \mathrm{H}, 7.25$. Found: C, 86.23; H, 7.15.

5-Methoxy-3,3-diphenylcyclohex-1-ene (6b). Yield: $0.016 \mathrm{~g}(64 \%)$. ${ }^{1} \mathrm{H} \mathrm{NMR}\left(\delta, \mathrm{CDCl}_{3}\right): 7.36-6.90(\mathrm{~m}, 10 \mathrm{H}, \mathrm{Ph}), 6.08\left(\mathrm{~d},{ }^{2} J_{\mathrm{HH}}=9.2\right.$ $\left.\mathrm{Hz}, 1 \mathrm{H}, \mathrm{CH}_{2} \mathrm{CH}=\mathrm{CH}\right), 5.71\left(\mathrm{~m}, 1 \mathrm{H}, \mathrm{CH}_{2} \mathrm{CH}=\mathrm{CH}\right), 3.50(\mathrm{~m}, 1 \mathrm{H}, \mathrm{OCH})$, $3.10\left(\mathrm{~s}, 3 \mathrm{H}, \mathrm{OCH}_{3}\right), 2.91\left(\mathrm{~d},{ }^{2} J_{\mathrm{HH}}=12.5 \mathrm{~Hz}, 1 \mathrm{H}, \mathrm{CH}_{2}\right), 2.40\left(\mathrm{dt},{ }^{2} J_{\mathrm{HH}}\right.$ $\left.=17.1 \mathrm{~Hz},{ }^{3} J_{\mathrm{HH}}=5.2 \mathrm{~Hz}, 1 \mathrm{H}, \mathrm{CH}_{2}\right), 2.33\left(\mathrm{t},{ }^{2} J_{\mathrm{HH}}=12.1 \mathrm{~Hz}, 1 \mathrm{H}\right.$, $\left.\mathrm{CH}_{2}\right), 2.10\left(\mathrm{dd},{ }^{2} J_{\mathrm{HH}}=17.1 \mathrm{~Hz},{ }^{2} J_{\mathrm{HH}}=9.5 \mathrm{~Hz}, 1 \mathrm{H}, \mathrm{CH}_{2}\right) \cdot{ }^{13} \mathrm{C}\left\{{ }^{1} \mathrm{H}\right\}$ $\operatorname{NMR}\left(\delta, \mathrm{CDCl}_{3}\right): 134.7\left(\mathrm{CH}_{2} \mathrm{CH}=\mathrm{CH}\right), 125.0\left(\mathrm{CH}_{2} \mathrm{CH}=\mathrm{CH}\right), 149.5-$ $120.8(\mathrm{Ph}), 73.6(\mathrm{OCH}), 55.1(\mathrm{OMe}), 50.7(\mathrm{C}), 42.0\left(\mathrm{CH}_{2}\right), 32.3\left(\mathrm{CH}_{2}\right)$. EI-MS $\mathrm{m} / \mathrm{z}$ (\%, relative intensity): $264(\mathrm{M}+, 12 \%)$. Anal. Calcd for $\mathrm{C}_{18} \mathrm{H}_{18} \mathrm{O}$ : C, 86.36; H, 7.25. Found: C, 86.23; H, 7.15.

5-Ethoxy-3,3-diphenylcyclohex-1-ene (6c). Yield: $0.019 \mathrm{~g} \mathrm{(73 \% ).}$ ${ }^{1} \mathrm{H}$ NMR $\left(\delta, \mathrm{CDCl}_{3}\right): 7.31-7.19(\mathrm{~m}, 10 \mathrm{H}, \mathrm{Ph}), 6.09\left(\mathrm{~d},{ }^{2} J_{\mathrm{HH}}=8.4\right.$ $\left.\mathrm{Hz}, 1 \mathrm{H}, \mathrm{CH}_{2} \mathrm{CH}=\mathrm{CH}\right), 5.88\left(\mathrm{~m}, 1 \mathrm{H}, \mathrm{CH}_{2} \mathrm{CH}=\mathrm{CH}\right), 3.50(\mathrm{~m}, 1 \mathrm{H}, \mathrm{OCH})$, $3.45\left(\mathrm{q},{ }^{2} J_{\mathrm{HH}}=7.0 \mathrm{~Hz}, \mathrm{OCH}_{2} \mathrm{CH}_{3}\right), 2.72\left(\mathrm{~d},{ }^{2} J_{\mathrm{HH}}=12.3 \mathrm{~Hz}, 1 \mathrm{H}, \mathrm{CH}_{2}\right)$, $2.52\left(\mathrm{~m}, 1 \mathrm{H}, \mathrm{CH}_{2}\right), 2.21\left(\mathrm{~m}, 1 \mathrm{H}, \mathrm{CH}_{2}\right), 2.12\left(\mathrm{~m}, 1 \mathrm{H}, \mathrm{CH}_{2}\right), 1.16(\mathrm{t}$, $\left.{ }^{2} J_{\mathrm{HH}}=7.0 \mathrm{~Hz}, \mathrm{CH}_{2} \mathrm{CH}_{3}\right) \cdot{ }^{13} \mathrm{C}\left\{{ }^{1} \mathrm{H}\right\} \mathrm{NMR}\left(\delta, \mathrm{CDCl}_{3}\right): 134.5\left(\mathrm{CH}_{2} \mathrm{CH}=\right.$ $\mathrm{CH}), 125.2\left(\mathrm{CH}_{2} \mathrm{CH}=\mathrm{CH}\right), 149.5-120.4(\mathrm{Ph}), 70.3(\mathrm{OCH}), 65.1$ $\left(\mathrm{OCH}_{2}\right), 50.5(\mathrm{C}), 42.4\left(\mathrm{CH}_{2}\right), 32.2\left(\mathrm{CH}_{2}\right), 15.4\left(\mathrm{CH}_{3}\right)$. EI-MS $\mathrm{m} / \mathrm{z}(\%$, relative intensity): $278\left(\mathrm{M}^{+}, 14 \%\right)$. Anal. Calcd for $\mathrm{C}_{20} \mathrm{H}_{22} \mathrm{O}: \mathrm{C}, 86.29$; H, 7.97. Found: C, 86.34; H, 7.86.

5-Isopropoxy-3,3-diphenylcyclohex-1-ene (6d). Yield: $0.020 \mathrm{~g}$ $(75 \%) .{ }^{1} \mathrm{H}$ NMR $\left(\delta, \mathrm{CDCl}_{3}\right): 7.32-6.98(\mathrm{~m}, 10 \mathrm{H}, \mathrm{Ph}), 6.11\left(\mathrm{~d},{ }^{2} J_{\mathrm{HH}}\right.$ $\left.=9.4 \mathrm{~Hz}, 1 \mathrm{H}, \mathrm{CH}_{2} \mathrm{CH}=\mathrm{CH}\right), 5.88\left(\mathrm{~m}, 1 \mathrm{H}, \mathrm{CH}_{2} \mathrm{CH}=\mathrm{CH}\right), 3.65(\mathrm{~m}$, $\left.1 \mathrm{H}, \mathrm{OCH}(\mathrm{Me})_{2}\right), 3.52(\mathrm{~m}, 1 \mathrm{H}, \mathrm{OCH}), 2.69\left(\mathrm{~d},{ }^{2} J_{\mathrm{HH}}=12.3 \mathrm{~Hz}, 1 \mathrm{H}\right.$, $\left.\mathrm{CH}_{2}\right), 2.42\left(\mathrm{dt},{ }^{2} J_{\mathrm{HH}}=17.3 \mathrm{~Hz},{ }^{3} J_{\mathrm{HH}}=5.2 \mathrm{~Hz}, 1 \mathrm{H}, \mathrm{CH}\right), 2.16(\mathrm{~m}, 1 \mathrm{H}$, $\left.\mathrm{CH}_{2}\right), 2.05\left(\mathrm{dd},{ }^{2} J_{\mathrm{HH}}=17.3 \mathrm{~Hz},{ }^{2} J_{\mathrm{HH}}=9.5 \mathrm{~Hz}, 1 \mathrm{H}, \mathrm{CH}_{2}\right), 1.05(\mathrm{~m}$, $\left.6 \mathrm{H}, 2 \mathrm{CH}_{3}\right),{ }^{13} \mathrm{C}\left\{{ }^{1} \mathrm{H}\right\}$ NMR $\left(\delta, \mathrm{CDCl}_{3}\right): 134.2\left(\mathrm{CH}_{2} \mathrm{CH}=\mathrm{CH}\right), 125.4$ $\left(\mathrm{CH}_{2} \mathrm{CH}=\mathrm{CH}\right), 149.5-120.2(\mathrm{Ph}), 69.1(\mathrm{OCH}), 68.1\left(\mathrm{OCH}\left(\mathrm{CH}_{3}\right)_{2}\right)$, $50.5(\mathrm{C}), 42.8\left(\mathrm{CH}_{2}\right), 32.2\left(\mathrm{CH}_{2}\right), 22.4\left(\mathrm{CH}_{3}\right), 22.2\left(\mathrm{CH}_{3}\right)$. EI-MS m/z (\%, relative intensity): $292\left(\mathrm{M}^{+}, 5 \%\right)$. Anal. Calcd for $\mathrm{C}_{21} \mathrm{H}_{24} \mathrm{O}: \mathrm{C}$, 86.26; H, 8.27. Found: C, 86.33; H, 8.19.

Preparation of $\left[\mathrm{Ru}^{\prime}\right]-\mathrm{C} \equiv \mathbf{C C H}_{\mathbf{2}} \mathbf{C}(\mathbf{P h})_{2} \mathbf{C H}=\mathrm{CH}_{\mathbf{2}}\left(\mathbf{7}^{\prime}\right)$. Complex $\mathbf{4}^{\prime}$ $(0.300 \mathrm{~g}, 0.334 \mathrm{mmol})$ was treated with excess sodium methoxide $(0.020$ $\mathrm{g}, 0.370 \mathrm{mmol})$ in methanol $(10 \mathrm{~mL})$, and the light-yellow precipitate formed immediately. Stirring was continued until no further solid was formed. The precipitate was filtered, washed with methanol $(2 \times 5$ $\mathrm{mL})$, and dried under vacuum to give complex $7^{\prime}(0.242 \mathrm{~g}$, yield $89 \%)$. ${ }^{1} \mathrm{H}$ NMR $\left(\delta, \mathrm{CDCl}_{3}\right): 7.88-7.00(\mathrm{~m}, 30 \mathrm{H}, \mathrm{Ph}), 5.22\left(\mathrm{~d},{ }^{2} J_{\mathrm{HH}}=17.5\right.$ $\left.\mathrm{Hz}, 1 \mathrm{H},=\mathrm{CH}_{2}\right), 5.13\left(\mathrm{~d},{ }^{2} J_{\mathrm{HH}}=10.7 \mathrm{~Hz}, 1 \mathrm{H},=\mathrm{CH}_{2}\right), 4.67(\mathrm{~s}, 5 \mathrm{H}$, $\mathrm{Cp}), 3.81\left(\mathrm{~s}, 2 \mathrm{H}, \mathrm{CH}_{2}\right), 1.99-2.70(\mathrm{~m}, 6 \mathrm{H}, \mathrm{dppp}) .{ }^{13} \mathrm{C}\left\{{ }^{1} \mathrm{H}\right\} \mathrm{NMR}(\delta$, $\left.\mathrm{CD}_{2} \mathrm{Cl}_{2}\right)$ : $147.3-125.6(\mathrm{~m}, \mathrm{Ph}), 147.1(\mathrm{~s},=\mathrm{CH}), 114.8\left(\mathrm{~s},=\mathrm{CH}_{2}\right), 104.3$ $\left(\mathrm{s}, \mathrm{C}_{\beta}\right), 97.9\left(\mathrm{t},{ }^{2} J_{\mathrm{PC}}=24.5 \mathrm{~Hz}, \mathrm{C}_{\alpha}\right), 83.7(\mathrm{~s}, \mathrm{Cp}), 55.7\left(\mathrm{~s}, \mathrm{CPh}_{2}\right), 35.5$ (s, $\left.\mathrm{CH}_{2}\right), 26.4-21.5$ (m, dppp). ${ }^{31} \mathrm{P}\left\{{ }^{1} \mathrm{H}\right\} \mathrm{NMR}\left(\delta, \mathrm{CDCl}_{3}\right)$ : 46.9. Anal. Calcd for $\mathrm{C}_{50} \mathrm{H}_{46} \mathrm{P} 2 \mathrm{Ru}: \mathrm{C}, 74.15 ; \mathrm{H}, 5.72$. Found: $\mathrm{C}, 74.32 ; \mathrm{H}, 5.88$.

Preparation of $\left[\left[\mathrm{Ru}^{\prime}\right]=\mathrm{C}=\mathrm{C}(\mathrm{Me}) \mathrm{CH}_{2} \mathrm{C}(\mathrm{Ph})_{2} \mathrm{CH}=\mathrm{CH}_{2}\right]\left[\mathrm{BF}_{4}\right]\left(8^{\prime}\right)$. A flask was charged with $\mathbf{7}^{\prime}(0.810 \mathrm{~g}, 1.00 \mathrm{mmol})$ in dichloromethane $(50 \mathrm{~mL})$ under nitrogen. MeOTf $(0.15 \mathrm{~mL}, 1.1 \mathrm{mmol})$ was added dropwise at room temperature, and the color of the solution changed from yellow to orange immediately. After the mixture was stirred about $10 \mathrm{~min}$, the volume of the solvent was reduced to $5 \mathrm{~mL}$ under vacuum, and then the residue mixture was added to $30 \mathrm{~mL}$ of diethyl ether. The precipitate thus formed was filtered, washed with diethyl ether $(2 \times 5$ $\mathrm{mL}$ ), and dried under vacuum to give the final product $\mathbf{8}^{\prime}$ as a chestnut brown powder $(0.870 \mathrm{~g}$, yield $89 \%) .{ }^{1} \mathrm{H}$ NMR $\left(\delta, \mathrm{CDCl}_{3}\right)$ : $7.39-6.70$ $(\mathrm{m}, 30 \mathrm{H}, \mathrm{Ph}), 6.54\left(\mathrm{dd},{ }^{3} J_{\mathrm{HH}}=17.5 \mathrm{~Hz},{ }^{3} J_{\mathrm{HH}}=10.7 \mathrm{~Hz}, 1 \mathrm{H},=\mathrm{CH}_{2}\right)$, $5.28(\mathrm{~s}, 5 \mathrm{H}, \mathrm{Cp}), 5.25\left(\mathrm{~d},{ }^{3} J_{\mathrm{HH}}=10.7 \mathrm{~Hz}, 1 \mathrm{H},=\mathrm{CH}_{2}\right), 4.52\left(\mathrm{~d},{ }^{3} J_{\mathrm{HH}}=\right.$ $\left.17.5 \mathrm{~Hz}, 1 \mathrm{H},=\mathrm{CH}_{2}\right), 2.80\left(\mathrm{~s}, 2 \mathrm{H}, \mathrm{CH}_{2}\right), 2.87-1.93(\mathrm{~m}, 6 \mathrm{H}, \mathrm{dppp})$, $1.07\left(\mathrm{~s}, 3 \mathrm{H}, \mathrm{CH}_{3}\right) .{ }^{13} \mathrm{C}\left\{{ }^{1} \mathrm{H}\right\} \mathrm{NMR}\left(\delta, \mathrm{CD}_{2} \mathrm{Cl}_{2}\right): 348.2\left(\mathrm{t},{ }^{2} J_{\mathrm{CP}}=15.5\right.$ $\left.\mathrm{Hz}, \mathrm{C}_{\alpha}\right), 147.3-117.8(\mathrm{Ph}), 146.2(\mathrm{~s},=\mathrm{CH}), 117.6\left(\mathrm{~s},=\mathrm{CH}_{2}\right), 115.7$ $\left(\mathrm{s}, \mathrm{C}_{\beta}\right), 93.1$ (s, Cp), $54.0\left(\mathrm{~s}, \mathrm{C}_{\gamma}\right) .{ }^{31} \mathrm{P}\left\{{ }^{1} \mathrm{H}\right\} \operatorname{NMR}\left(\delta, \mathrm{CDCl}_{3}\right): 35.5$. Anal. Calcd for $\mathrm{C}_{50} \mathrm{H}_{47} \mathrm{BF}_{4} \mathrm{P}_{2} \mathrm{Ru}: \mathrm{C}, 64.12 ; \mathrm{H}, 5.07$. Found: $\mathrm{C}, 64.23$; H, 5.21 .

Synthesis of $\boldsymbol{\pi}$-Cyclic Allene Complex 9. A solution of $\mathrm{HBF}_{4} \cdot \mathrm{Et}_{2} \mathrm{O}$ in diethyl ether was added dropwise at $-20^{\circ} \mathrm{C}$ to a stirred solution of 2b $(0.100 \mathrm{~g}, 0.102 \mathrm{mmol})$ in $20 \mathrm{~mL}$ of diethyl ether. Immediately, an insoluble solid formed, but the addition was continued until no further solid was formed. The solution was then decanted, and the brown solid was washed with diethyl ether $(3 \times 5 \mathrm{~mL})$ and dried in vacuo to give 9. Yield: $0.100 \mathrm{~g}(88 \%)$. Spectroscopic data for 9, ${ }^{1} \mathrm{H}$ NMR $(\delta$, $\left.\mathrm{CDCl}_{3}\right): 7.80-6.73(\mathrm{~m}, 40 \mathrm{H}, \mathrm{Ph}), 6.50(\mathrm{~s}, 1 \mathrm{H}, \mathrm{CH}), 5.30(\mathrm{~s}, 5 \mathrm{H}, \mathrm{Cp})$, 
$2.75\left(\mathrm{~d},{ }^{2} J_{\mathrm{HH}}=12.9 \mathrm{~Hz}, 1 \mathrm{H}, \mathrm{CH}_{2}\right), 2.43(\mathrm{~m}, 1 \mathrm{H},=\mathrm{CH}), 2.18(\mathrm{br}, 1 \mathrm{H}$, $\left.\mathrm{CHCH}_{3}\right), 1.74\left(\mathrm{~m}, 1 \mathrm{H}, \mathrm{CH}_{2}\right), 1.38\left(\mathrm{~d},{ }^{3} J_{\mathrm{HH}}=6.1 \mathrm{~Hz}, 3 \mathrm{H}, \mathrm{CH}_{3}\right) .{ }^{13} \mathrm{C}-$ $\left\{{ }^{1} \mathrm{H}\right\} \mathrm{NMR}\left(\delta, \mathrm{CDCl}_{3}\right): 151.5-120.1(\mathrm{Ph}), 90.4(\mathrm{~s}, \mathrm{Cp}), 58.4\left(\mathrm{~s}, \mathrm{C}_{\gamma}\right)$, $51.3\left(\mathrm{~s}, \mathrm{CH}_{2}\right), 42.5(\mathrm{~s}, \mathrm{CH}), 35.6(\mathrm{~s}, \mathrm{CH}), 20.3\left(\mathrm{~s}, \mathrm{CH}_{3}\right) .{ }^{31} \mathrm{P}\left\{{ }^{1} \mathrm{H}\right\} \mathrm{NMR}$ $\left(\delta, \mathrm{CDCl}_{3}\right): 121.7\left(\mathrm{~d},{ }^{2} J_{\mathrm{PP}}=60.5 \mathrm{~Hz}, \mathrm{P}(\mathrm{OPh})_{3}\right), 45.0\left(\mathrm{~d},{ }^{2} J_{\mathrm{PP}}=60.5\right.$ $\left.\mathrm{Hz}, \mathrm{PPh}_{3}\right)$. Spectroscopic data of the other diastereomer, ${ }^{1} \mathrm{H}$ NMR $(\delta$, $\left.\mathrm{CDCl}_{3}\right): 7.80-6.73(\mathrm{~m}, 40 \mathrm{H}, \mathrm{Ph}), 5.27$ (s, 5H, Cp), $4.96(\mathrm{~s}, 1 \mathrm{H}, \mathrm{CH})$, $2.85(\mathrm{~m}, 1 \mathrm{H},=\mathrm{CH}), 2.71\left(\mathrm{~d},{ }^{2} J_{\mathrm{HH}}=13.0 \mathrm{~Hz}, 1 \mathrm{H}, \mathrm{CH}_{2}\right), 2.06(\mathrm{~m}, 1 \mathrm{H}$, $\left.\mathrm{CH}_{2}\right), 1.68$ (br, $\left.1 \mathrm{H}, \mathrm{CHCH}_{3}\right), 1.37\left(\mathrm{~d},{ }^{3} J_{\mathrm{HH}}=6.0 \mathrm{~Hz}, 3 \mathrm{H}, \mathrm{CH}_{3}\right) .{ }^{13} \mathrm{C}-$ $\left\{{ }^{1} \mathrm{H}\right\}$ NMR $\left(\delta, \mathrm{CDCl}_{3}\right): 151.5-120.1(\mathrm{Ph}), 91.2(\mathrm{~s}, \mathrm{Cp}), 58.2\left(\mathrm{~s}, C_{\gamma}\right)$, $50.9\left(\mathrm{~s}, \mathrm{CH}_{2}\right), 42.6(\mathrm{~s}, \mathrm{CH}), 35.5(\mathrm{~s}, \mathrm{CH}), 19.8\left(\mathrm{~s}, \mathrm{CH}_{3}\right) .{ }^{31} \mathrm{P}\left\{{ }^{1} \mathrm{H}\right\} \mathrm{NMR}$ $\left(\delta, \mathrm{CDCl}_{3}\right): 124.7\left(\mathrm{~d},{ }^{2} J_{\mathrm{PP}}=58.2 \mathrm{~Hz}, \mathrm{P}(\mathrm{OPh})_{3}\right), 45.4\left(\mathrm{~d},{ }^{2} J_{\mathrm{PP}}=58.2\right.$ $\left.\mathrm{Hz}, \mathrm{PPh}_{3}\right)$. MS (FAB+) m/z: $985.3\left(\mathrm{M}^{+}\right), 739.3\left(\mathrm{CpRuPPh}{ }_{3} \mathrm{P}(\mathrm{OPh})_{3}\right)$. Anal. Calcd for $\mathrm{C}_{60} \mathrm{H}_{53} \mathrm{BF}_{4} \mathrm{O}_{3} \mathrm{P}_{2} \mathrm{Ru}$ : C, 67.23; H, 4.98. Found: C, 67.29; $\mathrm{H}, 4.87$.

General Procedure for the Synthesis of Alkoxy Cyclic Carbene Complexes 10. A solution of complex 3c $(0.100 \mathrm{~g}, 0.095 \mathrm{mmol})$ in alcohol or aqueous acetone $(20 \mathrm{~mL})$ was stirred for $1 \mathrm{~h}$ at room temperature under a nitrogen atmosphere. The resulting solution was reduced to about $3 \mathrm{~mL}$, which was slowly added to $50 \mathrm{~mL}$ of vigorously stirred diethyl ether to afford the reddish orange precipitate. The powder was filtered off and washed with diethyl ether and hexanes, to give the corresponding alkoxy cyclic carbene complex $\mathbf{1 0 .}$

Complex 10a. Yield: $0.093 \mathrm{~g}(91 \%) .{ }^{1} \mathrm{H}$ NMR $\left(\delta, \mathrm{CDCl}_{3}\right)$ : $7.51-$ $6.67\left(\mathrm{~m}, 41 \mathrm{H}, \mathrm{Ph}\right.$ and $\left.\mathrm{C}_{\beta} \mathrm{H}\right), 5.24(\mathrm{~s}, 5 \mathrm{H}, \mathrm{Cp}), 4.82\left(\mathrm{~d},{ }^{2} J_{\mathrm{HH}}=18.2 \mathrm{~Hz}\right.$, $\left.1 \mathrm{H}, \mathrm{C}_{\alpha} \mathrm{CH}_{2}\right), 3.41\left(\mathrm{~d},{ }^{2} J_{\mathrm{HH}}=18.2 \mathrm{~Hz}, 1 \mathrm{H}, \mathrm{C}_{\alpha} \mathrm{CH}_{2}\right), 2.95\left(\mathrm{~d},{ }^{2} J_{\mathrm{HH}}=\right.$ $\left.17.7 \mathrm{~Hz}, 1 \mathrm{H}, \mathrm{C}_{\delta} \mathrm{H}_{2}\right), 2.20\left(\mathrm{~d},{ }^{2} \mathrm{~J}_{\mathrm{HH}}=17.7 \mathrm{~Hz}, 1 \mathrm{H}, \mathrm{C}_{\delta} \mathrm{H}_{2}\right) \cdot{ }^{13} \mathrm{C}\left\{{ }^{1} \mathrm{H}\right\} \mathrm{NMR}$ $\left(\delta, \mathrm{CDCl}_{3}\right): 300.5\left(\mathrm{br}, \mathrm{C}_{\alpha}\right), 172.2\left(\mathrm{C}_{\gamma}\right), 146.6\left(\mathrm{C}_{\beta}\right), 151.2-120.8(\mathrm{Ph})$, $92.2(\mathrm{Cp}), 66.0\left(\mathrm{C}_{\alpha} \mathrm{CH}_{2}\right), 48.4(\mathrm{C}), 42.7\left(\mathrm{C}_{\delta}\right) .{ }^{31} \mathrm{P}\left\{{ }^{1} \mathrm{H}\right\} \mathrm{NMR}(\delta$, $\left.\mathrm{CDCl}_{3}\right): 136.9\left(\mathrm{~d},{ }^{2} J_{\mathrm{PP}}=59.5 \mathrm{~Hz}, \mathrm{P}(\mathrm{OPh})_{3}\right), 55.7\left(\mathrm{~d},{ }^{2} J_{\mathrm{PP}}=59.5 \mathrm{~Hz}\right.$, $\left.\mathrm{PPh}_{3}\right)$. MS (FAB+) m/z: $987.3\left(\mathrm{M}^{+}\right), 739.3(\mathrm{CpRuPPh}$ P(OPh). Anal. Calcd for $\mathrm{C}_{59} \mathrm{H}_{51} \mathrm{BF}_{4} \mathrm{O}_{4} \mathrm{P}_{2} \mathrm{Ru}$ : C, 65.99; H, 4.79. Found: C, 65.88; H, 4.75 .

Complex 10b. Yield: $0.096 \mathrm{~g}(93 \%) .{ }^{1} \mathrm{H} \mathrm{NMR}\left(\delta, \mathrm{CDCl}_{3}\right): 7.78-$ $6.52\left(\mathrm{~m}, 41 \mathrm{H}, \mathrm{Ph}\right.$ and $\left.\mathrm{C}_{\beta} \mathrm{H}\right), 5.05(\mathrm{~s}, 5 \mathrm{H}, \mathrm{Cp}), 4.72\left(\mathrm{~d},{ }^{2} J_{\mathrm{HH}}=18.3 \mathrm{~Hz}\right.$, $\left.1 \mathrm{H}, \mathrm{C}_{\alpha} \mathrm{CH}_{2}\right), 3.38\left(\mathrm{~s}, 3 \mathrm{H}, \mathrm{CH}_{3}\right), 3.36\left(\mathrm{~d},{ }^{2} J_{\mathrm{HH}}=18.3 \mathrm{~Hz}, 1 \mathrm{H}, \mathrm{C}_{\alpha} \mathrm{CH}_{2}\right)$, $2.78\left(\mathrm{~d},{ }^{2} J_{\mathrm{HH}}=18.0 \mathrm{~Hz}, 1 \mathrm{H}, \mathrm{C}_{\delta} \mathrm{H}_{2}\right), 2.12\left(\mathrm{~d},{ }^{2} J_{\mathrm{HH}}=18.0 \mathrm{~Hz}, 1 \mathrm{H}\right.$, $\left.\mathrm{C}_{\delta} \mathrm{H}_{2}\right) .{ }^{13} \mathrm{C}\left\{{ }^{1} \mathrm{H}\right\} \operatorname{NMR}\left(\delta, \mathrm{CDCl}_{3}\right): 300.5\left(\mathrm{br}, \mathrm{C}_{\alpha}\right), 168.4\left(\mathrm{C}_{\gamma}\right), 145.2$ $\left(\mathrm{C}_{\beta}\right), 151.5-120.1(\mathrm{~m}, \mathrm{Ph}), 92.2(\mathrm{Cp}), 67.1\left(\mathrm{C}_{\alpha} \mathrm{CH}_{2}\right), 57.6\left(\mathrm{OCH}_{3}\right)$, $47.5(\mathrm{C}), 42.0\left(\mathrm{C}_{\delta}\right) .{ }^{31} \mathrm{P}\left\{{ }^{1} \mathrm{H}\right\} \mathrm{NMR}\left(\delta, \mathrm{CDCl}_{3}\right): 136.8\left(\mathrm{~d},{ }^{2} J_{\mathrm{PP}}=58.5\right.$ $\left.\mathrm{Hz}, \mathrm{P}(\mathrm{OPh})_{3}\right), 55.3\left(\mathrm{~d},{ }^{2} J_{\mathrm{PP}}=58.5 \mathrm{~Hz}, \mathrm{PPh}_{3}\right)$. MS $(\mathrm{FAB}+) \mathrm{m} / z: 1001.3$ $\left(\mathrm{M}^{+}\right), 739.3\left(\mathrm{CpRuPPh}{ }_{3} \mathrm{P}(\mathrm{OPh})_{3}\right)$. Anal. Calcd for $\mathrm{C}_{60} \mathrm{H}_{53} \mathrm{BF}_{4} \mathrm{O}_{4} \mathrm{P}_{2} \mathrm{Ru}$ : C, 66.24; H, 4.91. Found: C, 66.27; H, 4.82.
Complex 10c. Yield: $0.093 \mathrm{~g}(89 \%) .{ }^{1} \mathrm{H}$ NMR $\left(\delta, \mathrm{CDCl}_{3}\right): 7.68-$ $6.52\left(\mathrm{~m}, 41 \mathrm{H}, \mathrm{Ph}\right.$ and $\left.\mathrm{C}_{\beta} \mathrm{H}\right), 4.94(\mathrm{~s}, 5 \mathrm{H}, \mathrm{Cp}), 4.64\left(\mathrm{~d},{ }^{2} J_{\mathrm{HH}}=18.0 \mathrm{~Hz}\right.$, $\left.1 \mathrm{H}, \mathrm{C}_{\alpha} \mathrm{CH}_{2}\right), 3.73\left(\mathrm{q}, 2 \mathrm{H},{ }^{2} J_{\mathrm{HH}}=6.5 \mathrm{~Hz}, \mathrm{OCH}_{2} \mathrm{CH}_{3}\right), 3.48\left(\mathrm{~d},{ }^{2} J_{\mathrm{HH}}=\right.$ $\left.18.0 \mathrm{~Hz}, 1 \mathrm{H}, \mathrm{C}_{\alpha} \mathrm{CH}_{2}\right), 2.77\left(\mathrm{~d},{ }^{2} J_{\mathrm{HH}}=18.1 \mathrm{~Hz}, 1 \mathrm{H}, \mathrm{C}_{\delta} \mathrm{H}_{2}\right), 2.25(\mathrm{~d}$, $\left.{ }^{2} J_{\mathrm{HH}}=18.1 \mathrm{~Hz}, 1 \mathrm{H}, \mathrm{C}_{\delta} \mathrm{H}_{2}\right), 1.32\left(\mathrm{t},{ }^{2} J_{\mathrm{HH}}=6.5 \mathrm{~Hz}, 3 \mathrm{H}, \mathrm{CH}_{3}\right) \cdot{ }^{13} \mathrm{C}\left\{{ }^{1} \mathrm{H}\right\}$ $\operatorname{NMR}\left(\delta, \mathrm{CDCl}_{3}\right): 300.7\left(\mathrm{br}, \mathrm{C}_{\alpha}\right), 168.0\left(\mathrm{C}_{\gamma}\right), 145.3\left(\mathrm{C}_{\beta}\right), 151.5-121.7$ (m, Ph), $91.8(\mathrm{Cp}), 67.0\left(\mathrm{C}_{\alpha} \mathrm{CH}_{2}\right), 66.6\left(\mathrm{OCH}_{2} \mathrm{CH}_{3}\right), 47.6(\mathrm{C}), 42.2$ $\left(\mathrm{C}_{\delta}\right), 14.1\left(\mathrm{CH}_{3}\right) .{ }^{31} \mathrm{P}\left\{{ }^{1} \mathrm{H}\right\} \mathrm{NMR}\left(\delta, \mathrm{CDCl}_{3}\right): 136.8\left(\mathrm{~d},{ }^{2} J_{\mathrm{PP}}=58.8 \mathrm{~Hz}\right.$, $\left.\mathrm{P}(\mathrm{OPh})_{3}\right), 54.8\left(\mathrm{~d},{ }^{2} J_{\mathrm{PP}}=58.8 \mathrm{~Hz}, \mathrm{PPh}_{3}\right) . \mathrm{MS}(\mathrm{FAB}+) \mathrm{m} / \mathrm{z}: 1015.3$ $\left(\mathrm{M}^{+}\right), 739.3\left(\mathrm{CpRuPPh} 3 \mathrm{P}(\mathrm{OPh})_{3}\right)$. Anal. Calcd for $\mathrm{C}_{61} \mathrm{H}_{55} \mathrm{BF}_{4} \mathrm{O}_{4} \mathrm{P}_{2} \mathrm{Ru}$ : C, 66.49; H, 5.03. Found: C, 66.55; H, 5.12.

Single-Crystal X-ray Diffraction Analysis of 5. Single crystals of 5 suitable for an X-ray diffraction study were grown as mentioned above. A single crystal of dimensions $0.20 \times 0.15 \times 0.10 \mathrm{~mm}^{3}$ was glued to a glass fiber and mounted on an SMART CCD diffractometer. The diffraction data were collected using $3 \mathrm{~kW}$ sealed-tube Mo K $\alpha$ radiation $(T=295 \mathrm{~K})$. Exposure time was $5 \mathrm{~s}$ per frame. SADABS ${ }^{19}$ (Siemens area detector absorption) absorption correction was applied, and decay was negligible. Data were processed, and the structure was solved and refined by the SHELXTL ${ }^{20}$ program. The structure was solved using direct methods and confirmed by Patterson methods refining on intensities of all data to give $\mathrm{R} 1=0.1050$ and $\mathrm{wR} 2=$ 0.1291 for 11596 unique observed reflections $(I>2 \sigma(I))$. Hydrogen atoms were placed geometrically using the riding model with thermal parameters set to 1.2 times that for the atoms to which the hydrogen is attached and 1.5 times that for the methyl hydrogens.

Acknowledgment. This research is supported by the National Science Council and National Center of High-Performance Computing of Taiwan, the Republic of China.

Supporting Information Available: Complete crystallographic data for $\mathbf{5}$ (CIF) and preparations and spectroscopic data of complexes $\mathbf{1}, \mathbf{1}^{\prime}, \mathbf{2} \mathbf{a}, \mathbf{2} \mathbf{a}^{\prime}, \mathbf{2} \mathbf{b}, \mathbf{2} \mathbf{b}^{\prime}, \mathbf{2} \mathbf{c}, \mathbf{3} \mathbf{a}^{\prime}, \mathbf{3} \mathbf{c}$, and $\mathbf{9}^{\prime}$. This material is available free of charge via the Internet at http://pubs.acs.org.

JA074951P

(19) The SADABS program is based on the method of Blessing, see: Blessing, R. H. Acta Crystallogr., Sect. A 1995, 51, 33.

(20) SHELXTL: Structure Analysis Program, version 5.04; Siemens Industrial Automation Inc.: Madison, WI, 1995. 